\title{
Disease Resistance Mechanisms in Plants
}

\author{
Ethan J. Andersen ${ }^{1}$, Shaukat Ali ${ }^{2}$, Emmanuel Byamukama ${ }^{2}$, Yang Yen ${ }^{1}{ }^{(D)}$ and \\ Madhav P. Nepal ${ }^{1, *(D)}$ \\ 1 Department of Biology and Microbiology, South Dakota State University, Brookings, 57007 SD, USA; \\ ethan.andersen@sdstate.edu (E.A.); yang.yen@sdstate.edu (Y.Y.) \\ 2 Department of Agronomy, Horticulture, and Plant Science, South Dakota State University, Brookings, \\ 57007 SD, USA; shaukat.ali@sdstate.edu (S.A.); emmanuel.byamukama@sdstate.edu (E.B.) \\ * Correspondence: madhav.nepal@sdstate.edu; Tel.: +1-605-688-5971
}

Received: 31 May 2018; Accepted: 29 June 2018; Published: 4 July 2018

\begin{abstract}
Plants have developed a complex defense system against diverse pests and pathogens. Once pathogens overcome mechanical barriers to infection, plant receptors initiate signaling pathways driving the expression of defense response genes. Plant immune systems rely on their ability to recognize enemy molecules, carry out signal transduction, and respond defensively through pathways involving many genes and their products. Pathogens actively attempt to evade and interfere with response pathways, selecting for a decentralized, multicomponent immune system. Recent advances in molecular techniques have greatly expanded our understanding of plant immunity, largely driven by potential application to agricultural systems. Here, we review the major plant immune system components, state of the art knowledge, and future direction of research on plant-pathogen interactions. In our review, we will discuss how the decentralization of plant immune systems have provided both increased evolutionary opportunity for pathogen resistance, as well as additional mechanisms for pathogen inhibition of such defense responses. We conclude that the rapid advances in bioinformatics and molecular biology are driving an explosion of information that will advance agricultural production and illustrate how complex molecular interactions evolve.
\end{abstract}

Keywords: coevolution; defense response; disease resistance; nucleotide-binding leucine-rich repeat; plant immunity; plant-pest interaction; pathogenesis; pattern recognition receptor; phytopathology; resistance gene

\section{Introduction}

\subsection{Plant Disease Resistance Has Emerged as a Complex, Multicomponent System}

The agricultural revolution of approximately 10,000 years ago intensified humanity's relationship with plants. Since survival largely depended on yield, early farmers would have selected plants based on multiple factors, including their ability to resist disease. Multiple plant diseases recorded in ancient times were often attributed to supernatural causes, but phytopathological observations can be traced back to the third and fourth centuries B.C. in the writings of Aristotle's student Theophrastus [1]. Microbiology during the enlightenment enabled systematic classification of pathogenic organisms, newly visible under compound microscopes. Early experiments in the 19th century demonstrated the efficacy of fungicides, such as the Bordeaux mixture of copper sulfate and calcium oxide [2]. Also in the 19th century, pathogenic microbes were demonstrated to be the causal agents of plant diseases by Heinrich Anton de Bary [3]. Understanding of heritability and genetics, developed in the early 20th century, allowed researchers to identify sources of heritable resistance, called resistance genes ( $R$ genes) [4,5]. R genes were further described by Harold Henry Flor's groundbreaking gene-for-gene model [6], correlated with avirulence genes present in the pathogen that create an 
incompatible response. Mechanisms for resistance utilizing $\mathrm{R}$ genes were then elucidated following advances in chemistry and molecular biology later in the 20th century $[7,8]$. The advances in molecular techniques and genomics of the early 21st century drove the discovery of numerous classes of genes that encode regulators of disease resistance and susceptibility [9]. R genes were found to be only one set of participants in a web of interacting factors. Recent molecular research has revealed that plant resistance relies on a complex regulatory system that controls plant defense responses, greatly building upon the simple structure of H. H. Flor's gene-for-gene model. Plant immune system components participate in pathogen detection, signal transduction, or defense response. Selection pressures drive the evolution of plants with complex detection systems and pathogens with sophisticated evasion techniques, as outlined in the zig-zag model [10]. This review focuses on these components, and how they are involved in immunity. We do not aim to completely exhaust every aspect of each component, as whole reviews are dedicated to a single class of one factor. Instead, we hope to present the conceptual framework of phytopathogen resistance, as supported by examples. We will first briefly review which components are involved in this plant immune system, and how pathogens have evolved to subvert defenses.

\subsection{Plant Defense Relies on Detection and Response}

Investigation into the molecular basis of pathogen resistance reveals a suite of cellular receptors that performs direct detection of pathogenic molecules. Pattern recognition receptors (PRRs) within the cell membrane detect pathogen-associated molecular patterns (PAMPs) and wall-associated kinases (WAKs) detect damage-associated molecular patterns (DAMPs) that result from cellular damage during infection $[11,12]$. Receptors with nucleotide-binding domains and leucine-rich repeats (NLRs) detect effectors that pathogens use to facilitate infection [13]. PRRs, WAKs, and NLRs initiate one of many signaling cascades that have yet to be completely elucidated. Mitogen-activated protein kinases (MAPKs), G-proteins, ubiquitin, calcium, hormones, transcription factors (TFs), and epigenetic modifications regulate the expression of pathogenesis-related (PR) genes [14-18]. This leads to various responses that prevent further infection: hypersensitive response (HR), production of reactive oxygen species (ROS), cell wall modification, closure of stomata, or the production of various anti-pest proteins and compounds (e.g., chitinases, protease inhibitors, defensins, and phytoalexins) $[19,20]$. As now understood from molecular techniques, pathogen resistance in plants involves various organelles and classes of both proteins and non-protein compounds, each of which are required to regulate defense response (see Figure 1). Factors in each of these roles affect various other signaling systems, such as growth and abiotic stress response. An improved understanding of plant-pathogen interaction requires that we fully describe these molecular interactions that take place when a compatible pathogen interacts with plant tissue. First, however, we must briefly describe the pathogens that elicit these responses, and how their evolution has led to the complex immune system that plants possess. 


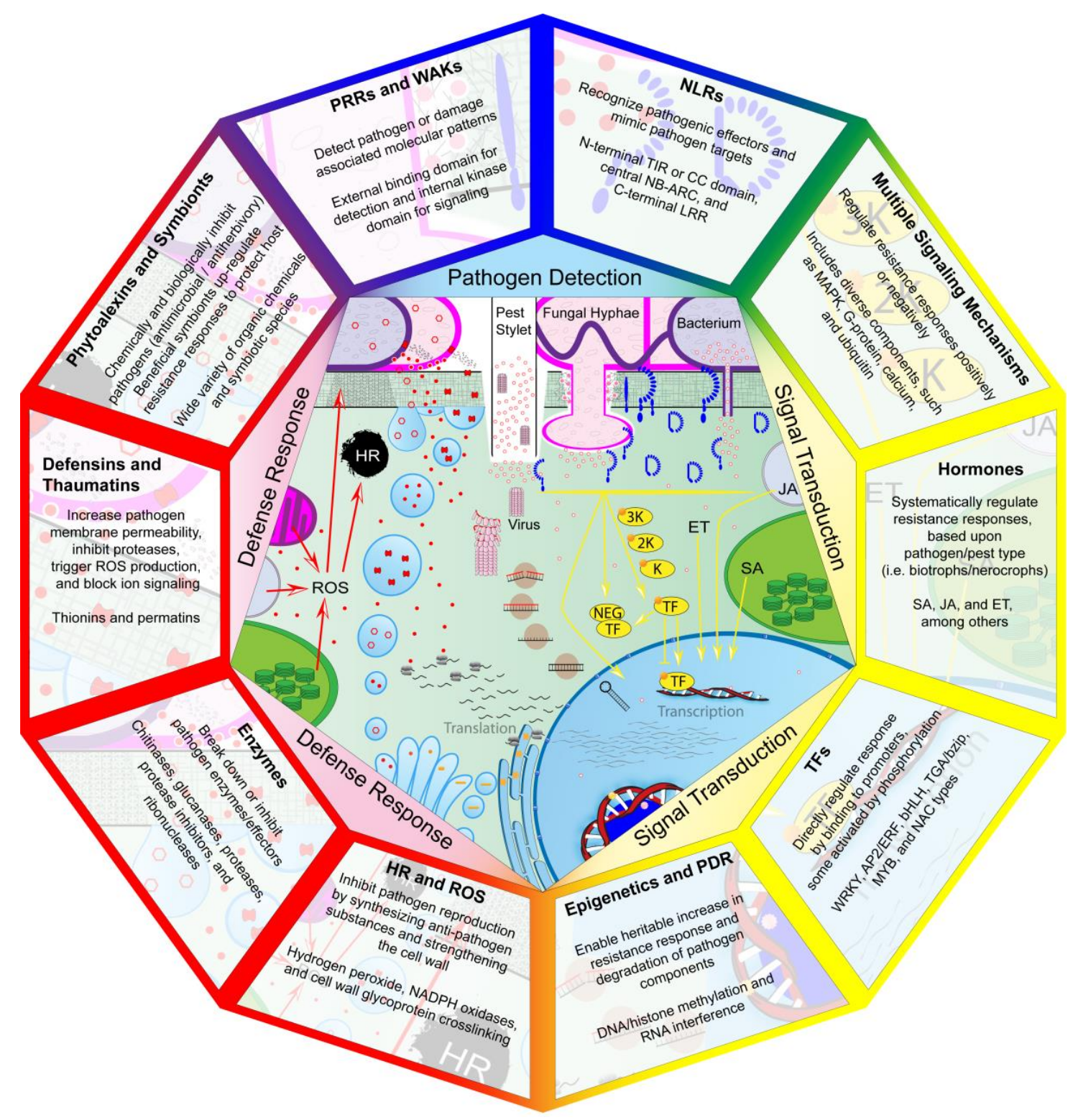

Figure 1. Components of plant disease resistance mechanisms involved in pathogen detection, signal transduction, and defense response (detection in the upper center and progressing around clockwise, ending in defense response in the upper left). Pathogenic elicitors (cell components or effectors) produced by bacteria, fungi, insects, nematodes, or viruses trigger plant receptors to initiate signaling cascades. Activated receptors (blue) then initiate one of many signal transduction pathways or directly act as transcription factors (TFs). Signal transduction pathways (yellow) include mitogen-activated protein kinase (MAPK) cascades, calcium ion signaling, hormone production, TF activity, and epigenetic regulation. These factors trigger the expression of genes associated with defense responses, such as those regulating the production of reactive oxygen species (ROS), antimicrobial enzymes, defensins, and phytoalexins. These defense-related compounds (red) actively inhibit pathogen reproduction or make further infection more difficult. Breakdown of pathogenic cell components by defense compounds leads to further release of receptor-triggering elicitors, increasing the resistance response. Multiple organelles are involved in defense response, including chloroplasts and peroxisomes for hormone production as well as the nucleus, endoplasmic reticulum, and Golgi apparatus for antimicrobial protein production. PRR: Pattern recognition receptors; WAK: wall-associated kinases; NLR: nucleotide-binding domains and leucine-rich repeats; PDR: pathogen-derived resistance; HR: hypersensitive response; TIR: N-terminal Toll/interleukin-1 receptor-like; CC: coiled-coil; SA: salicylic acid; JA: jasmonic acid; ET: ethylene. 


\subsection{Pathogen Virulence Relies on Attack and Evasion}

Diverse species and races of pathogens drive plant populations to evolve a highly varied set of immune receptors and modes of response [8,21,22]. Pathogens respond by evolving mechanisms to evade host perception or negate defense responses [10]. Pathogens often subvert PAMP-triggered immunity (PTI) through effectors, which can be secreted through various systems. The bacterium Xanthomonas translucens, for example, secretes 20-40 effectors through a type III secretion system, resembling a tube that transfers effectors into wheat cytoplasm [23]. Other members of the Xanthomonas genus utilize a type VI secretion system, which transfers effectors extracellularly [24]. Pathogens can also increase virulence by transferring effector genes from one species to another, called horizontal gene transfer. Such an event has been proposed to describe the transfer of the necrosis-inducing ToxA gene from Parastagonospora nodorum to Pyrenophora tritici-repentis, which causes the disease tan spot in wheat [25]. Plant effector-triggered immunity (ETI) detects these effectors and initiates a defense response. Such responses must also be varied as pathogens differ in how they extract nutrients: biotrophs from living tissue and necrotrophs from dead tissue. HR intended to inhibit biotrophs only facilitates necrotroph infection [26]. Hemi-biotrophs trick the plant by switching from biotrophy to necrotrophy [27], producing effectors in waves that differ by tissue and infection stage [28]. The complex system leading to pathogen resistance, described in Figure 1, has been subverted at various levels, with pathogens evolving effectors that compromise many of the various signaling steps. As we review next, the first stage of pathogen detection relies upon the recognition of molecules unique to pathogens or resulting from pathogen infection.

\section{Pathogen Detection}

\subsection{PRRs and WAKs Detect PAMPs and DAMPS}

PRRs are able to recognize a wide array of microbial components, including fungal carbohydrates [29], bacterial proteins [30], and viral nucleic acids [31]. These receptors often possess leucine-rich repeats (LRRs) that bind to extracellular ligands, transmembrane domains necessary for their localization in the plasma membrane, and cytoplasmic kinase domains for signal transduction through phosphorylation [11]. LRRs are highly divergent, associated with their ability to bind to diverse elicitors. Many PRRs rely on the regulatory protein brassinosteroid insensitive 1-associated receptor kinase 1 (BAK1) and other somatic embryogenesis receptor-like kinases (SERKs) [32,33]. Extensive signaling is not always initiated, as some PRRs, upon activation, release kinase domains that travel to the nucleus to trigger transcriptional reprogramming [34]. Molecules detected by PRRs are diverse: bacterial (flagellin, elongation factor EF-Tu, and peptidoglycan) [35-37], fungal (chitin, xylanase) [38,39], oomycete ( $\beta$-glucan and elicitins) [40,41], viral (double stranded RNA) [31], and insect (aphid-derived elicitors) [33]. Although many of these studies were conducted to elucidate specific molecular interactions in Arabidopsis, wheat PRRs TaLRK10, TaRLP1.1, and TaRLK-R1-3 have been associated with resistance to rust (fungi of the genus Puccinia) via detection of fungal PAMPs [42-44].

Unlike the PRRs that detect non-self pathogen molecules upon infection, other receptors perceive damage by recognizing cellular components that have been disrupted by pathogenic enzymes. This has been shown in Arabidopsis with WAK1 perception of oligogalacturonides [45] or DORN1/LecRK-I.9 perception of extracellular ATP [46]. WAKs possess an N-terminal, extracellular galacturonan-binding domain that interacts with pectins in the cell wall, and cytoplasmic kinase domains, similar to the structure of PRRs. WAK1 and WAK2 perceive oligogalacturonic acid, resulting from plant cell wall pectin degradation by fungal enzymes [45]. Plant lectins are able to recognize carbohydrates that originate directly from pathogens or from damage incurred during infection [47]. Many PAMPs and DAMPs contain carbohydrates (i.e., lipopolysaccharides, peptidoglycans, oligogalacturonides, and cellulose) and are recognized by PRRs/WAKs with lectin domains, such as lectin receptor kinases [47]. Plants detect many extracellular molecules that indicate pathogen infection [48], such as 
extracellular DNA, ATP, and NAD(P). Pathogens have evolved to interfere in the detection of PAMPs and reduce the efficacy of PTI. Cladosporium fulvum and Magnaporthe oryzae produce chitin-binding proteins in order to prevent plant perception (i.e., Avr4 and Slp1, respectively) [49-51]. Pathogens also produce effectors to thwart many aspects of plant immunity, which plants have developed ways to overcome, as outlined in the zig-zag model [10]. In order to recognize these infection-facilitating pathogen effectors, plants utilize another, more varied class of proteins.

\subsection{NLRs Detect Pathogen Effectors}

NLRs, also known as R genes, are among the fastest evolving gene families. Their products, upon detection of pathogenic effectors, undergo a conformational shift from a condensed, ADP-bound state to an open ATP-bound state with exposed $\mathrm{N}$-terminal domains for the initiation of downstream signaling [52-54]. N-terminal Toll/interleukin-1 receptor-like (TIR) or coiled-coil (CC) domains precede an evolutionarily conserved domain with a Nucleotide-Binding site present in Apoptotic protease-activating factor, R proteins, and Caenorhabditis elegans death-4 protein (NB-ARC), followed by and a highly variable LRR [52]. CC-NBS-LRR genes (CNL genes) are found in both monocots and dicots, but TIR-NBS-LRR genes (TNL genes) are restricted only to the latter [55]. Similar to PRRs, variability in the LRR provides these receptors with the ability to recognize various effector structures. Unlike PRRs, NLRs are generally located in the cytoplasm and possess LRRs at the C-terminal end. The NB-ARC contains many conserved motifs: P-loop/Walker-A, resistance nucleotide-binding site A (RNBS-A), Kinase-2/Walker-B, RNBS-B, RNBS-C, GLPL, RNBS-D, and MHDV, GLPL and MHDV named after the conserved amino acids present. However, not all motifs are required for function, exemplified by the rice Pb1 CNL protein, which lacks a P-loop [56]. Wu et al. (2016 and 2017) have shown that NLRs operate in networks, differentiating sensor and helper NLRs, along with NLRs required for cell death (NRCs) $[57,58]$. NLRs have emerged as complex receptors that can detect a variety of changes, both through non-self and modified-self recognition [59]. NLR interactions are not always advantageous, as mismatching of NLRs in hybrids can result in autoimmunity [60]. NB-ARCs similar to those found in NLRs are found in many different species, from the bacterial Streptomyces coelicolor genome [61] to those of nematode [62] and human [63], the latter two also involved in programmed cell death. Many NLR genes are located in extra-pericentromeric clusters [64], which experience high rates of chromosomal recombination. These genes evolve quickly through duplications, chromosomal rearrangements, and unequal crossing over [65]. Transposable elements also play a role in the evolution of regulatory sequences, like promoters [66,67]. Translocation of NLR genes to unlinked loci increases the likelihood of functional diversification [57]. Similar to PRRs, many effector-NLR interactions have been elucidated in Arabidopsis [68]. NLRs become activated by direct interaction with pathogen effectors [69] or by detecting modification of the effector's target protein [21,70], modification of a target-mimicking decoy protein [71], or modification of the NLR itself [72-74]. One of the most well-studied NLR-effector interactions involves the NLRs RPM1 and RPS2, which perceive the targeting of resistance negative regulator RIN4 by Pseudomonas syringae effectors AvrRpt2 and AvrRpm1 [75]. Unlike other NLRs, RPS2 and RPM1 are located within the plasma membrane, since their guardee, RIN4, is also associated with the plasma membrane [76]. After activation, RPM1 associates with the promoter-binding AtTIP49a negative regulator, to upregulate resistance responses [77].

NLRs have diverse structures that may include integrated decoy domains that exist as targets for effectors, such as TF sequences that effectors regularly target. Arabidopsis resistance to Ralstonia solanacearum 1 (RRS1) has a WRKY TF domain at the C-terminal end, to directly bind to promoter sequences [78]. The Ralstonia solanacearum effector PopP2 modifies this WRKY domain, which triggers activation of the NLR $[79,80]$. NLRs are also able to dimerize, such as CNL proteins RGA5 and RGA4 in rice, in which RGA5 directly binds to M. oryzae effectors Avr-Pia and Avr1-Co39 [81,82]. Much research is still necessary to elucidate how NLRs self-associate or dimerize, specifically genes with economic importance, such as wheat stem rust resistance genes [83]. Similar to 
PRR reliance on BAK1, NLRs rely on other proteins to transmit signals. CNLs and TNLs associate with non-race-specific disease resistance 1 (NDR1) and enhanced disease susceptibility 1 (EDS1) proteins, respectively [84-86]. NLRs are also able to localize to specific areas of the cell, such as the endosomes or nucleus. Potato CNL protein R3a, when triggered by Phytophthora infestans effector Avr3a ${ }^{\mathrm{KI}}$, moves to endosomes, where it recruits additional effectors [87]. Barley CNL MLA proteins accumulate in the nucleus to interfere with WRKY TFs to downregulate immunity [88]. Plants also use exocytosis to move immune receptors to the plasma membrane and secrete antimicrobial substances. As a way to benefit from disruption of antimicrobial compound production, some pathogen effectors interfere with protease secretion [89], vesicular trafficking via proteasome degradation [90], and endocytosis [91]. P. nodorum and P. tritici-repentis effectors SnTox1 and PtrToxA utilize susceptibility genes Snn1 and Tsn1, which encode WAK and NLR proteins, respectively [92-96]. This hijacking of immune components allows necrotrophic pathogens to trigger HR through reactive oxygen species (ROS) accumulation [97]. PRRs, WAKs, and NLRs rely on complex signaling mechanisms to initiate defense responses. MAPKs, hormones, TFs, and other components play major roles in this signal transduction.

\section{Signal Transduction}

\subsection{Resistance Involves Multiple Signaling Mechanisms}

Receptors activate signaling mechanisms that are common to many cellular processes, including MAPKs, G-proteins, ubiquitin, and calcium fluctuations. In the general model of MAPK signaling, membrane-bound Ras proteins facilitate the conversion of GTP to GDP, phosphorylating MAPKKK (Raf) proteins, which then phosphorylate MAPKK (MEK) proteins, leading to the phosphorylation of MAPK (ERK) proteins [14]. The involvement of MAPK in many cellular processes has led to the identification of MAPK genes in Arabidopsis, which contains 60 MAPKKKs, 10 MAPKKs, and 20 MAPKs [98]. Initiated by bacterial flagellin and elongation factor interaction, PRRs FLS2 and EFR dimerize with BAK1 and trigger MAPK signaling [99,100]. Pathogen pectin degradation detected by WAK1 and WAK2 also initiates a MAPK cascade $[45,101,102]$. Studies in tomato show MAPK genes involved in signal transduction of NLR perception as well [103-105]. Defense responses can also be downregulated by MAPK signaling [106], and pathogens have developed effectors that interfere with MAPK signaling to suppress resistance responses [107]. Similarly, the heterotrimeric G-protein and G-protein-coupled receptor (GPCR) system has been heavily studied due to its involvement in numerous cellular processes. Extracellular ligands bind to the transmembrane GPCR, causing the exchange of GDP for GTP in the $\alpha$ subunit of the G-protein complex, causing a dissociation of the $\alpha$ subunit from the $\beta-\gamma$ subunit complex, initiating further signaling [108]. Hydrolysis of GTP by the $\alpha$ subunit then causes the subunits to re-associate. Metazoan systems make more use of G-protein signaling [109-111], but G-proteins possess roles in HR and stomatal closure [15]. Ubiquitination and subsequent protein degradation by the proteasome also has activity in many signaling systems, including defense. Components are regulated positively by the repression of their degradation or negatively by targeted degradation [17]. Pathogens have evolved effectors to interfere with the ubiquitin proteasome system in an attempt to disrupt this signaling and facilitate infection [17]. Small ubiquitin-like modifiers (SUMOs) are also utilized by plants to regulate response, and pathogens disrupt this signaling as well [112].

Receptors triggering fluctuations in calcium ions $\left(\mathrm{Ca}^{2+}\right)$ act as signaling mechanisms to trigger responses to symbiotic or pathogenic microbes [16,113]. Calmodulin (CaM), calcium-dependent protein kinases (CDPKs), and calcineurin B-like proteins detect calcium to activate diverse families of TFs, including calmodulin-binding transcription activators (CAMTAs) [113,114]. CaM is involved in ROS production through MAPK cascade initiation [115]. Calcium signaling controls hormone activation and the expression of NDR1 and EDS1 proteins [113]. CDPKs move to the nucleus to phosphorylate WRKY TFs involved in RPS2 and RPM1 ETI [116]. This molecular signal can be transmitted through hormones that have roles in many different stress and developmental responses [14]. Similar to calcium signaling, 
fluctuations in hormones drive differential expression of defense response genes. While sustained MAPK activity during ETI allows for less reliance on hormonal regulation, transient MAPK activity during PTI depends heavily upon hormonal signaling [117].

\subsection{Plant Hormones Systematically Initiate and Repress Resistance}

Hormones operating downstream of pathogen detection provide another layer of regulation and take many forms: salicylic acid (SA), jasmonic acid (JA), ethylene (ET), abscisic acid (ABA), nitric oxide $(\mathrm{NO})$, cytokinins (CK), gibberellin (GA), auxin, and brassinosteroids (BR). Along with affecting a multitude of developmental and response functions, including crosstalk with other hormones, SA plays a central role in local and systemic resistance responses to biotrophic and hemi-biotrophic pathogens [118]. SA and MAPK cascades can act upstream of each other, with some cascades triggering SA activity, or SA triggering MAPK cascades [118]. Signaling is transferred from receptors to SA through NDR1 for CNL receptors and a combination of EDS1 and phytoalexin deficient 4 (PAD4) for TNL receptors $[86,119,120]$. Through a complex web of interactions, SA transfers the signal that a pathogen is present through the action of TFs to induce the expression of defense-related genes. After initiated by signaling, SA leads to the reduction of disulfide bonds in the oligomer protein nonexpressor of pathogen resistance gene 1 (NPR1) by thioredoxins, allowing its constituent monomers to pass from the cytosol into the nucleus, bind to the TF TGA (binding site: TGACG), and upregulate genes associated with resistance $[18,121]$. Taking advantage of this system, the Cochliobolus victoriae pathogenic effector, victorin, targets the thioredoxin TRX-h5, involved in the monomerization of NPR1, and triggers cell death through the action of Arabidopsis susceptibility protein LOV1 [122].

JA and ET play key roles in the plant's response to necrotrophic pathogens $[18,123-125]$ and herbivorous insects [126,127]. JA and ET upregulate the emission of volatile compounds in response to caterpillar herbivory, initiated by caterpillar oral secretions [128]. In order to subvert plant response, insect gut microbes can reduce the JA-mediated defense in plants [129]. Perception of bacterial flagellin enhances the production of ET as a signaling mechanism [130]. Without ET present, TF ethylene insensitive 3 (EIN3) is degraded by F-box protein-mediated ubiquitination and proteasome activity. ET inactivates receptors and the constitutive triple response1 (CTR1) protein, which stops the repression of EIN2 and EIN3, and allows upregulation of ET signaling, expression of defense genes, and necrotroph resistance [18,131]. This is also a target of pathogen interference, as the XopD effector of tomato pathogen Xanthomonas euvesicatoria desumoylates the TF SIERF4, to interfere with hormone signaling, specifically suppressing ET production and resistance [132]. Functioning of the hormones ABA, NO, auxin, CK, GA, and BR in immunity and development shows that defense and growth are closely linked [133], often inversely related. ABA is involved in various plant stresses [134], including the repression and promotion of resistance responses during presence and absence of abiotic stress, respectively [135]. Closure of stomata involves ABA signaling to regulate water loss, gas exchange, and pathogen access to tissue [136,137]. GA and ascorbic acid (AA) deficiencies lead to enhanced resistance $[138,139]$. Since hormones are broadly defined as systemic regulators, peptides can also function as plant hormones. Recently, the small peptide hormone systemin has been shown to be involved in system herbivory response, leading to changes in gene expression, specifically of neighboring plants that are not exposed to the biotic stress [140]. This indicates that plant hormones can trigger communication between individual plants to increase defense responses. Having discussed some of the major signaling factors, we now shift our attention to the proteins that directly alter transcription in the nucleus.

\subsection{TFs Play an Essential Role in Transcriptional Reprogramming}

Transcriptional reprogramming through TF activity plays roles at several levels of resistance: (1) basal expression of resistance components (e.g., receptors, kinases, response suppression proteins), (2) direct TF activity of activated receptor proteins, and (3) TFs activated downstream of receptor initiation (i.e., MAPK cascade leading to TF activation via phosphorylation [141]). Plant TFs are diverse 
in comparison to metazoan systems: homeodomain, MADS box, $\mathrm{C}_{2} \mathrm{H}_{2}$ zinc finger, AP2/ERF, bHLH, TGA/bZIP, MYB, NAC, and WRKY; the latter six families are especially involved in defense [131]. AP2/ERF defense-related TFs (binding to GCC boxes: GCCGCC) are associated with ethylene regulation and involved in positive regulation of rice resistance to Chilo suppressalis [142] and Arabidopsis resistance to Botrytis cinerea $[143,144]$. In the latter example, ethylene response factor 6 (ERF6) activates plant defensin 1.1 and 1.2 after MPK3/MPK6 phosphorylation [145]. An MYC2 TF, NaMYC2 regulates the production of nicotine, an anti-herbivory secondary metabolite from Nicotiana attenuata [146]. The chitin-triggered rice bZIP TF OsTGAP1 upregulates antimicrobial compound synthesis [147]. Abiotic stresses can also impact resistance signaling, like cold, drought, or wounding [148,149]. bHLH TF MYC2 works antagonistic to ethylene response factor 1 (ERF1) by downregulating resistance and upregulating wounding responses [150]. Aside from kinase phosphorylation, TFs can also be activated by modifications, such as proteolysis in no apical meristem (NAM)-Arabidopsis transcription activation factor (ATAF)-cup-shaped cotyledon (CUC2) (NAC) TF NTL6 [148]. TFs can also target specific aspects of infection, like barley HvNAC6 upregulating genes involved in resistance to Blumeria graminis penetration [151]. In addition to these classes of TFs, WRKYs appear to be involved in many of the thoroughly studied resistance responses.

WRKY TFs bind to W-box regions (TTGACC/T) and possess conserved WRKYGQK amino acid residues along with zinc finger domains [152]. In addition to their involvement in abiotic stresses, like drought and salt tolerance, WRKY TFs positively and negatively regulate the expression of genes associated with defense, including response to viruses [153]. WRKY TFs are classified into groups I, IIa-e, and III, with analysis of ancestral species (i.e., algae) leading to potential phylogenetic relationships [152]. Arabidopsis resistance to B. cinerea involves phosphorylation of WRKY33 by MPK3/MPK6, followed by WRKY33 binding to its own promoter and the promoters of components necessary for the synthesis of ethylene [154] and antimicrobial compounds (via phytoalexin deficient 3) [155]. By contrast, barley HvWRKY1 and HvWRKY2 repress PTI, disrupted by CNL protein mildew locus A10 (MLA10) after detection of the B. graminis effector AVR $\mathrm{A}_{10}$ [88]. Barley CNL protein MLA1 interacts with WRKY1 and MYB6 TFs, the latter upregulating B. graminis resistance [156]. Rice WRKY45 positively regulates blast resistance when activated by the CNL protein Pb1 [157]. Receptor TF activity is shown in resistance to X. oryzae, where rice PRR/RLK Xa21 is cleaved and sends a kinase domain to the nucleus that binds to the negative regulator OsWRKY62 [34,158]. The allelic variants encoding proteins OsWRKY45-1 and OsWRKY45-2 both positively regulate resistance to Magnaporthe grisea, but downregulate and upregulate resistance to X. oryzae, respectively [159]. WRKY TFs also interact with other families of TFs, such as bHLH TFs AtBZR1 and AtBES1/BZR2, working in conjunction with a WRKY TF to regulate BR signaling [160]. Wheat TFs TaWRKY49 and TaWRKY62 have been demonstrated to play roles in resistance to Puccinia striiformis, affecting the expression of genes associated with SA, JA, ET, and ROS [161].

Pathogens have evolved effectors that interfere with transcriptional reprogramming by blocking plant TF activity or directly promoting plant gene expression. P. infestans effectors prevent potato NAC TFs from moving from the endoplasmic reticulum to the nucleus [162]. P. syringae effector HopD1 interacts with the membrane-bound TF NTL9, suppressing effector-triggered immunity [163] and tobacco mosaic virus (TMV) also appears to interfere with the NAC TF ATAF2 to suppress resistance [164]. Pathogens also produce effectors that act as plant TFs [28]. Xanthomonas and Ralstonia bacteria produce transcriptional activator-like effectors (TALEs) that bind to plant susceptibility gene promoters [23,165]. Rice Xa10 and pepper Bs3 genes possess TALE-binding promoter sites for TALEs AvrXa10 and AvrBs3 involved in resistance to X. oryzae pv. oryzae and Xanthomonas campestris pv. vesicatoria, respectively [166,167]. While TFs directly trigger transcriptional reprogramming, an additional layer of regulation exists for response-related genes. 


\subsection{Epigenetic Regulation and PDR Provide Additional Regulatory Mechanisms}

Nucleic acids have roles as regulators of plant immunity and are critical targets of plant and pathogen degradation. Epigenetic changes can increase pathogen resistance through upregulation of response proteins or downregulation of response inhibitors. Pathogen exposure causes chromatin modification that affects expression of various plant defense response components [168]. DNA methylation, histone methylation/acetylation, RNA interference (RNAi), and recombination between homologous chromosomes influence plant defense [169]. Methylation of genes encoding resistance components has been shown to reduce pathogen resistance $[66,170,171]$. SA repression activity is facilitated by histone deacetylase HDA19 [172], which interacts with WRKY TFs in response to P. syringae [173]. SA analog treatment and P. syringae infection of Arabidopsis both result in histone acetylation and methylation of gene promoters [168,174]. Epigenetic regulation intensifies the host's reaction to likely threats, and ensures that host resources are not wasted on resistance to unlikely threats. The physiological cost of defense and longevity of pathogen inoculum both give a selective advantage to plants that can repress and prime responses. Epigenetic factors serve as another layer of regulation of resistance responses by the plant.

In contrast to the ligand-receptor resistance mechanisms discussed earlier, pathogen-derived resistance (PDR) involves the use of pathogen components to confer resistance. Inoculation of a plant with a less virulent form of the pathogen can cause the plant to become more resistant to later infection by a more virulent race/pathotype [175]. Barley primed with chemical elicitors produced progeny with enhanced resistance to the fungi Rhynchosporium commune [176]. Interestingly, priming to increase resistance of Fusarium graminearum by wheat caused an increase in F. graminearum mycotoxin production [177]. PDR to viruses often involves expression of viral coat proteins, replicases, and interfering RNAs $[178,179]$. Plants expressing the coat protein of a virus resist other viral strains [180] due to interference in viral disassembly that is necessary for viral replication. Viral sequences transcribed by the plant are used to generate microRNAs that interfere with viral transcription, which is necessary for viral replication within the host cell. RNAi is used as an antiviral mechanism that degrades pathogenic RNA. Some pathogens possess effectors that suppress RNA silencing [181-183], and RNAi is the underlying mechanism in the development of transgenic wheat with resistance to the wheat streak mosaic virus [184]. RNAi has also been proposed for development of nematode resistance in soybean [185]. Plants regulate defense components using microRNAs, alternative splicing, and alternative polyadenylation [186-194]. Pathogens have evolved the ability to use small RNAs as effectors that move into plant cells and repress host defense machinery [195]. In order to facilitate infection, Botrytis cinerea uses RNA silencing of the host [196] and Phytophthora sojae suppresses RNA silencing [182,197]. Ribonucleases (RNases) in the apoplast have also been correlated with increased resistance to RNA viruses [198] and antifungal activity [199-201]. The wheat wheatwin1 protein possesses both RNase and antifungal activity [202]. Corresponding to the diverse receptors and messengers that signal the presence of pests, plants possess a sophisticated array of defense tactics that restrict pathogens and pests from further infection, growth, herbivory, and reproduction.

\section{Defense Response}

\subsection{HR, ROS, and Cell Wall Modification Inhibit Pathogen Infection}

HR is one of the most commonly used immune responses, causing planned cell death in the area surrounding an infection. This establishes a quarantine zone to stop the pathogen from spreading, an effective technique for pathogens that require living tissue (biotrophs). Pathogen infection triggers the production of peroxidases in order to generate ROS, which are used in multiple aspects of the resistance response $[203,204]$. NADPH oxidases are necessary for the production of superoxide, which peroxidases use to generate hydrogen peroxide $\left(\mathrm{H}_{2} \mathrm{O}_{2}\right)$. One NADPH oxidase, RBOHD, associates with PRRs EFR and FLS2, and is phosphorylated by BIK1, triggering ROS production [205]. ROS trigger programmed cell death, and hydrogen peroxide moves to surrounding cells to initiate the 
production of compounds that prevent oxidative damage [206]. Transgenic plants that lack the ability to detoxify ROS compounds were found to have more intense responses to pathogens that trigger HR [207]. Along with assisting in HR, ROS are used to create environments unsuitable for pathogen survival and reproduction, described as an oxidative burst [208]. Therefore, ROS are directly involved at levels of signal transduction and defense response, inhibiting fungal spore germination [208]. In addition to peroxidases and NADPH oxidase, other enzymes produce ROS, including amine and oxalate oxidases [209]. Sclerotinia sclerotiorum, a necrotrophic fungus with a broad host range that includes many crops, produces oxalic acid, which suppresses plant oxidative burst [210] in the early stages of infection, but increases ROS production after establishment [211]. Wheat and barley produce oxalate oxidase proteins, also known as germins [212,213], which break down oxalic acid, increasing their pathogen resistance [214]. Transgenic crops with wheat or barley oxalate oxidase genes showed increased resistance to S. sclerotiorum [215-217] and other pests [218-221].

ROS mediate glycoprotein crosslinking, which strengthens cell walls [208,222]. Since fungi, bacteria, and nematodes need to penetrate the cell wall, this restricts pathogen movement and limits access to the nutrients necessary to complete reproduction. Bacterial pathogens, lacking some of the degradation enzymes that many fungi possess, use wounds and stomata in order to gain access to plant nutrients. Stomatal guard cells, recognizing bacterial PAMPs (i.e., flg22) and lipopolysaccharides, induce stomatal closure via SA and ABA signaling to prevent entry $[137,223]$. In response to this, P. syringae produces coronatine to initiate reopening of closed stomata [223] by interfering with hormone biosynthesis and mimicking phytohormones [28]. Once viewed as a passive way of pathogen entry into plant tissue, regulation of stomata has been demonstrated to include a complex defense mechanism, in addition to its response to abiotic stress. In addition to oxidase production, plants and pathogens generate many other factors that interfere with each other's carbohydrates, proteins, and lipids.

\subsection{Enzymes and Enzyme Inhibitors Counter Pathogenic Effectors and Facilitate Detection}

Fungi use enzymes like cellulases to degrade plant cell walls. Upon detection of these fungal proteins, plants respond by producing enzyme inhibitors and depositing callose and lignin to strengthen the cell wall [224]. In addition to cellulases, pathogens like F. graminearum and Fusarium culmorum degrade plant carbohydrates with pectinases and xylanases [225,226]. In a form of evolutionary retaliation, plants have evolved enzymes that degrade pathogen carbohydrates, including chitinases and $\beta-1-3$-glucanases $[227,228]$. This degradation of fungal cellular components not only inhibits microbial growth, but also makes PAMPs available to plant PRRs, thwarting the pest's attempt at evasion. Wheat chitinases, degrading a major component of fungal cell walls, inhibit fungal spore germination $[229,230]$. Recombinant wheat chitinases have been shown to possess antifungal activity against many different fungal species, not limited to wheat pathogenic fungi [231]. The chitin-binding Avr4 of $C$. fulvum protects chitin from plant chitinases [50]. Hevamine possesses chitinase and lysozyme activity and contains $\beta$ barrel structural domains [232], otherwise associated with a multitude of functions and generally associated with cellular metabolism [233]. Similar to chitinases, plant $\beta$-1,3-glucanases hydrolyze $\beta$-1,3-glucan in fungal cell walls, producing monomers that further stimulate plant defense responses $[234,235]$. This multifaceted approach aims at reducing the effectiveness of pathogenic components, as well as strengthening plant defenses. Since the components of cell walls are diverse (i.e., cellulose, hemicellulose, pectin, lignin, etc.), pathogens must have a diverse set of proteins to infect the host, leading to an even more complex arrangement of plant receptors and defense proteins. Thus, the evolutionary battle over the ability to penetrate or reinforce the cell wall is a microcosm for the overall coevolution of the plant-pathogen interaction.

Proteases released by both plants and pathogens evolved to reduce the efficacy of catalytic proteins (i.e., plant chitinase and fungal cellulase). Plants and pathogens also use protease inhibitors to impede the activity of these proteases [236]. Thomas and van der Hoorn discuss ten important types of proteases, grouping them based on location: apoplastic, cytonuclear, vacuolar, endomembrane [237], 
showing how proteases act at multiple levels in plant-pathogen interaction. The Fusarium verticillioides Zn-metalloproteinase fungalysin cleaves defense chitinases [238], but wheat produces hevein-like antimicrobial proteins, that inhibit fungalysin by binding to the enzyme without being cleaved [239], stopping the degradation of chitinases that are necessary to prevent infection. Barley protease inhibitors block the activity of Fusarium trypsin, chymotrypsin, and $\alpha$-amylase [240]. Wheat and barley $\alpha$-amylase inhibitors interfere with pest starch digestion by interfering with $\alpha$-amylase, used by insects and fungi to metabolize starches [241-245]. Both proteinaceous and non-proteinaceous $\alpha$-amylase inhibitors are produced, the latter being organic compounds that mimic $\alpha$-amylase substrates [245]. N. attenuata produces trypsin proteinase inhibitors along with nicotine to defend against Spodoptera exigua [246]. Plants may also detect pathogens through protease inhibitors. For example, C. fulvum, is perceived by tomato RLP Cf-2 detection of Avr2, which is initially produced to inhibit tomato proteases Rcr3 and PiP1 $[247,248]$. Oomycete P. infestans and nematode Globodera rostochiensis interfere with tomato protease activity $[249,250]$, exemplifying a multilayered system of protein-protein interactions.

Like proteins, lipids participate in many cellular activities. Lipids form major barriers that separate a host plant from prospective pathogens. Pathogens initiate infection after perception of cutin or other compounds of the waxy cuticle. Puccinia graminis and Blumeria graminis initiate appressoria formation upon contact with surface wax of wheat [251] and barley [252], respectively. Cutinases are then utilized by fungi to hydrolyze cutin into cutin monomers to move through the cuticle [253]. Plant lipases inhibit fungal infection, found in Arabidopsis [254] and wheat [255]. Lipid-transfer proteins also possess antimicrobial function linked to increased pathogen membrane permeability. However, details regarding how these proteins affect microbes remain to be elucidated [256]. Effectors that have activity within host cells, such as those of $P$. syringae, require lipid modification to move into the host cell [257], with NLR receptors that detect these effectors located in the plasma membrane instead of the cytoplasm $[258,259]$. Lipids can also be direct targets of pathogens or plant perception such as the Fusarium toxin fumonisin interference with sphingolipid metabolism [260], or defense responses triggered by bacterial lipopolysaccharide PAMPs [261,262]. Phospholipases and lipoxygenases (LOXs) are involved in the breakdown of phospholipids/galactolipids into free fatty acids for the production of defense components [263] and can act in stomatal closure [264]. Phospholipase activity, which is involved with various hormone and stress responses [265], may generate products that are directly involved in defense response, such as phosphatidic acid [263,266]. In addition to this general enzyme activity related to cellular components, plants have evolved specialized proteins that defend them from pathogen infection.

\subsection{Defensins and Thaumatin-Like Proteins Offensively Inhibit Pathogen Infection}

Defensins are a diverse class of small plant proteins that directly attack or inhibit invading microbes and parasitic plants [267]. Initially reported as barley [268] and wheat [269] $\gamma$-thionins, it was shown that they possess structural similarity to animal defensins $[270,271]$. Analogous to the action of many medical antibiotics, plant defensins interfere with pathogen protein synthesis and enzyme function. Barley defensins $\gamma$-hordothionin and $\omega$-hordothionin inhibit protein translation [268,272], and defensins can move into pathogen cytoplasm $[273,274]$. Triticum aestivum defensin 1 (Tad1) is expressed in the crown, and possesses antipathogen properties [275]. Defensins inhibit proteases [276], trigger pathogen ROS production [277], and block ion signaling [278]. Unlike animal defensins that inhibit bacterial growth, many plant defensins are antifungal, and are especially active in seeds. They make up $0.5 \%$ of the total seed protein and a substantial amount of proteins that are released from the seed coats, at 30\% [279]. Defensins have been found in many tissues [280] and may be induced during seasonal changes [275]. C-terminal hydrophobic and $\gamma$-core regions are critical for membrane interaction and antifungal activity, respectively [281,282]. Defensins contain scorpion toxin-like, knottin, and purothionin domains, with conserved cysteine residues that form a cysteine-knot structure composed of disulfide bridges. Scorpion toxins and some plant defensins both block potassium channels using similar protein domains $[283,284]$. Defensins cause an increase in pathogen membrane 
permeability that initiates necrosis [285]. Previous studies identified over 300 cysteine-rich defensin-like proteins in Arabidopsis [286] and Medicago truncatula [287]. Van Der Weerden and Anderson have proposed the classification of defensins into 18 groups based on species, structure, and function [288]. Plant defensins have potential as medical antibiotics, antitumor medication [289], and artificial sweeteners [290].

Thaumatin-like proteins, named after the protein thaumatin from Thaumatococcus daniellii [291], are also pathogenesis-related proteins. Barley thaumatin-like proteins bind to 1,3- $\beta$-D-glucans [292], associated with resistance to powdery mildew [293], F. graminearum [294], or general antifungal activity [295]. The antifungal thaumatin-like proteins osmotin (tobacco), zeamatin (maize), hordomatin (barley), avematin (oat), and trimatin (wheat) are permatins that form transmembrane pores in fungal membranes [295-298]. Like defensins, permatins accumulate in seeds [299]. Research in barley and wheat shows thaumatin-like proteins PRHv-1 and PWIR2, respectively, expressed along with other genes during fungal resistance responses [300,301], with similar sequences in oat [302]. Thaumatin-like proteins have potential as artificial sweeteners and influence the malting quality of barley [303]. Thaumatin-like proteins make up one of the 17 categories of PR proteins: oxidases and oxidase-like (PR-9, 15, and 16), chitinases (PR-3, 4, 8, and 11), $\beta$-1,3-glucanases (PR-2), endoproteinases (PR-7), proteinase inhibitors (PR-6), lipid-transfer proteins (PR-14), ribonuclease-like (PR-10), defensins and thionins (PR-12 and 13, respectively), thaumatin-like (PR-5), and the less understood antifungal (Pr-1) and functionally uncategorized (Pr-17) groups [20,304-306]. Additional mechanisms that plants use to deter pests involve non-protein compounds and assistance from other species.

\subsection{Phytoalexins and Beneficial Symbionts Are Chemical and Biological Plant Weapons}

Phytoalexins are organic compounds produced in response to invading pests to interfere with metabolism, development, and reproduction. Phytoalexins were initially investigated as defense compounds that protected potatoes from P. infestans. Several classes of plant chemicals have pesticide activity and those that are constitutively produced are described as phytoanticipins. A model phytoalexin used by Arabidopsis, camalexin, is produced in response to many different types of microbial pathogens and pests [307]. Camalexin is regulated by MAPK cascades [308] and WRKY TFs $[155,309,310]$. Some adaptive pathogens are able to detoxify this chemical [311]. Wheat produces benzoxazinoids (BXs), such as 2,4-dihydroxy-7-methoxy-1,4-benzoxazin-3-one (DIMBOA), which defends against microbes and insects, such as reducing transmission of barley yellow dwarf virus through aphid feeding [312-314]. Wheat pathogens Gaeumannomyces graminis and F. culmorum can detoxify BXs [315]. Wheat likely inherits genes required to convert 2,4-dihydroxy-1,4-benzoxazin-3-one (DIBOA) to DIMBOA through the progenitor of its $\mathrm{B}$ genome (chromosome 4B) since Aegilops speltoides accumulates DIMBOA, but Triticum urartu and Aegilops tauschii do not [316]. Additional phytoalexins in cereals include avenanthramides in oat and diterpenoids in rice [310]. As a phytoanticipin of the saponin group, avenacin A-1 is produced by oat root epidermis and forms pores in fungal membranes by interacting with fungal membrane sterols [317-319]. G. graminis var. avenae has evolved the ability to detoxify avenacin A-1 [320]. While phytoalexins have been found in many species [310] with classified allelopathic effects [321], some signaling mechanisms leading to production remain elusive. Phytoalexins may also show usefulness in medical applications [310,322]. Exogenous chemicals applied to crops, such as glyphosate-based herbicides, may increase crop susceptibility to disease [323].

In addition to producing pesticides, plants can recruit natural predators of herbivorous insects as a defense through the production of herbivore-induced plant volatiles. Caterpillars feeding on maize leaves induce the production of terpenoid compounds and indole, attracting parasitic wasps that feed on the caterpillars [324-326]. JA signaling is also activated, driven by volicitin from caterpillar oral secretions [128]. To protect themselves from herbivory, plants can also produce sticky substances that trap insects, such as resin and latex [327-329], along with increasing photosynthetic production [330]. Morphological features, like trichomes, reduce insect herbivory, in addition to 
many cellular components, such as flavonoids, tannins, terpenoids, alkaloids, and phenolics [331]. Aside from providing the plant with access to nutrients, some symbionts assist their host in pathogen defense. Wheat rhizobacteria have activity against the soilborne pathogen G. graminis through the production of antibiotic substances [332], and rice arbuscular mycorrhiza trigger improved immune responses to protect the host [333]. Mycorrhizae in corn have the ability to enhance production of DIMBOA [334]. Symbionts have been shown to affect resistance responses through repression of JA-mediated defense [335] or interference with ROS and $\beta$-1,3-glucanse production [336,337]. These interactions demonstrate the multilayered nature of the plant immune system.

\section{Conclusions and Future Directions}

Knowledge of plant-pathogen interactions will undoubtedly continue to flourish in the 21st century, driven by new molecular techniques and greater computational power. Phytopathology, like other fields, will continue to grow as more details emerge regarding plant-pathogen interactions. Research will be driven by several factors, such as disease pressures associated with modern agricultural practices and climate change, increasing the need for durable pathogen resistance in crops [338]. In addition to improving our knowledge of plant immunity, efforts will continue to alter crop genetics to develop better resistance. Continuing to alter the receptors necessary to initiate defense responses is likely the best route for development of resistance. NLRs may become a major tool of biotechnology, used to engineer resistance to any pathogen through the modified activity of the CRISPR/Cas9 system. One recent approach utilizes the activation of Arabidopsis NLR RPS5 by P. syringae protease AvrPphB cleavage of PBS1 [339,340]. Kim et al. showed that the cleavage site of PBS1 can be replaced with a cleavage site for other pathogen proteases, allowing for defense responses to be triggered by other pathogens [341]. While this technology is currently limited, future studies will likely engineer crops with novel R-genes that were not directly transferred from other species. In order to trigger the most effective defense response, engineering novel resistance pathways to different pathogens will also need to pair the receptors with the appropriate method of signal transduction. PDR may also have applications in genetic engineering, by allowing plants to express pathogen genes that promote resistance [342]. Future studies will also focus on understanding quantitative resistance and gene pyramiding, due to the durable resistance they hold [343], such as the multi-decade resistance found in barley cultivar NDB 112 [344-347]. Additional mechanisms of resistance regulation and response will be uncovered in future years, having applications to agricultural systems. Understanding pathogen resistance and plant immunity will greatly benefit agricultural production by reducing crop loss, and contribute to our understanding of the molecular interactions and coevolution that underlies this field and numerous applications to other biological systems.

Funding: This research was funded by the South Dakota Agricultural Experiment Station (SDAES) and USDA-NIFA Hatch Project Fund to M. Nepal.

Conflicts of Interest: The authors declare no conflict of interest.

\section{References}

1. Whetzel, H.H. An Outline of the History of Phytopathology; WB Saunders: Philadelphia, PA, USA, 1918.

2. Moutinho-Pereira, J.; Magalhaes, N.; Torres de Castro, L.; Manuela Chaves, M.; Torres-Pereira, J. Physiological responses of grapevine leaves to bordeaux mixture under light. Vitis 2001, 40, 117-121.

3. Kutschera, U.; Hossfeld, U. Physiological phytopathology: Origin and evolution of a scientific discipline. J. Appl. Bot. Food Qual. 2012, 85, 1-5.

4. Rhoades, V.H. The location of a gene for disease resistance in maize. Proc. Natl. Acad. Sci. USA 1935, 21, 243-246. [CrossRef] [PubMed]

5. Bushnell, W. The Cereal Rusts: Origins, Specificity, Structure, and Physiology; Elsevier: Amsterdam, The Netherlands, 2012; Volume 1.

6. Flor, H.H. Inheritance of pathogenicity in melampsora lini. Phytopathology 1942, 32, 653-669. 
7. Hammond-Kosack, K.E.; Jones, J. Resistance gene-dependent plant defense responses. Plant Cell 1996, 8, 1773-1791. [CrossRef] [PubMed]

8. Hammond-Kosack, K.E.; Jones, J.D. Plant disease resistance genes. Ann. Rev. Plant Biol. 1997, 48, $575-607$. [CrossRef] [PubMed]

9. Antolín-Llovera, M.; Ried, M.K.; Binder, A.; Parniske, M. Receptor kinase signaling pathways in plant-microbe interactions. Ann. Rev. Phytopathol. 2012, 50, 451-473. [CrossRef] [PubMed]

10. Jones, J.D.; Dangl, J.L. The plant immune system. Nature 2006, 444, 323-329. [CrossRef] [PubMed]

11. Zipfel, C. Plant pattern-recognition receptors. Trends Immunol. 2014, 35, 345-351. [CrossRef] [PubMed]

12. Decreux, A.; Messiaen, J. Wall-associated kinase WAK1 interacts with cell wall pectins in a calcium-induced conformation. Plant Cell Physiol. 2005, 46, 268-278. [CrossRef] [PubMed]

13. Dangl, J.L.; Horvath, D.M.; Staskawicz, B.J. Pivoting the plant immune system from dissection to deployment. Science 2013, 341, 746-751. [CrossRef] [PubMed]

14. Meng, X.; Zhang, S. MAPK cascades in plant disease resistance signaling. Ann. Rev. Phytopathol. 2013, 51, 245-266. [CrossRef] [PubMed]

15. Zhang, H.; Gao, Z.; Zheng, X.; Zhang, Z. The role of G-proteins in plant immunity. Plant Signal. Behav. 2012, 7, 1284-1288. [CrossRef] [PubMed]

16. Lecourieux, D.; Ranjeva, R.; Pugin, A. Calcium in plant defence-signalling pathways. New Phytol. 2006, 171, 249-269. [CrossRef] [PubMed]

17. Marino, D.; Peeters, N.; Rivas, S. Ubiquitination during plant immune signaling. Plant Physiol. 2012, 160, 15-27. [CrossRef] [PubMed]

18. Robert-Seilaniantz, A.; Grant, M.; Jones, J.D. Hormone crosstalk in plant disease and defense: More than just jasmonate-salicylate antagonism. Ann. Rev. Phytopathol. 2011, 49, 317-343. [CrossRef] [PubMed]

19. Juge, N. Plant protein inhibitors of cell wall degrading enzymes. Trends Plant Sci. 2006, 11, $359-367$. [CrossRef] [PubMed]

20. van Loon, L.C.; Rep, M.; Pieterse, C.M. Significance of inducible defense-related proteins in infected plants. Annu. Rev. Phytopathol. 2006, 44, 135-162. [CrossRef] [PubMed]

21. Dangl, J.L.; Jones, J.D. Plant pathogens and integrated defence responses to infection. Nature 2001, 411, 826-833. [CrossRef] [PubMed]

22. Gururani, M.A.; Venkatesh, J.; Upadhyaya, C.P.; Nookaraju, A.; Pandey, S.K.; Park, S.W. Plant disease resistance genes: Current status and future directions. Physiol. Mol. Plant Pathol. 2012, 78, 51-65. [CrossRef]

23. Boch, J.; Bonas, U. Xanthomonas AvrBs3 family-type III effectors: Discovery and function. Ann. Rev. Phytopathol. 2010, 48, 419-436. [CrossRef] [PubMed]

24. Gardiner, D.M.; Upadhyaya, N.M.; Stiller, J.; Ellis, J.G.; Dodds, P.N.; Kazan, K.; Manners, J.M. Genomic analysis of Xanthomonas translucens pathogenic on wheat and barley reveals cross-kingdom gene transfer events and diverse protein delivery systems. PLoS ONE 2014, 9, e84995. [CrossRef] [PubMed]

25. Friesen, T.L.; Stukenbrock, E.H.; Liu, Z.; Meinhardt, S.; Ling, H.; Faris, J.D.; Rasmussen, J.B.; Solomon, P.S.; McDonald, B.A.; Oliver, R.P. Emergence of a new disease as a result of interspecific virulence gene transfer. Nat. Genet. 2006, 38, 953-956. [CrossRef] [PubMed]

26. Glazebrook, J. Contrasting mechanisms of defense against biotrophic and necrotrophic pathogens. Annu. Rev. Phytopathol. 2005, 43, 205-227. [CrossRef] [PubMed]

27. Vleeshouwers, V.G.; Oliver, R.P. Effectors as tools in disease resistance breeding against biotrophic, hemibiotrophic, and necrotrophic plant pathogens. Mol. Plant Microbe Interact. 2014, 27, 196-206. [CrossRef] [PubMed]

28. Toruño, T.Y.; Stergiopoulos, I.; Coaker, G. Plant-pathogen effectors: Cellular probes interfering with plant defenses in spatial and temporal manners. Ann. Rev. Phytopathol. 2016, 54, 419-441. [CrossRef] [PubMed]

29. de Jonge, R.; van Esse, H.P.; Kombrink, A.; Shinya, T.; Desaki, Y.; Bours, R.; van der Krol, S.; Shibuya, N.; Joosten, M.H.; Thomma, B.P. Conserved fungal LysM effector Ecp6 prevents chitin-triggered immunity in plants. Science 2010, 329, 953-955. [CrossRef] [PubMed]

30. Sun, Y.; Li, L.; Macho, A.P.; Han, Z.; Hu, Z.; Zipfel, C.; Zhou, J.-M.; Chai, J. Structural basis for flg22-induced activation of the arabidopsis FLS2-BAK1 immune complex. Science 2013, 342, 624-628. [CrossRef] [PubMed]

31. Niehl, A.; Wyrsch, I.; Boller, T.; Heinlein, M. Double-stranded RNAs induce a pattern-triggered immune signaling pathway in plants. New Phytol. 2016, 211, 1008-1019. [CrossRef] [PubMed] 
32. Monaghan, J.; Zipfel, C. Plant pattern recognition receptor complexes at the plasma membrane. Curr. Opin. Plant Biol. 2012, 15, 349-357. [CrossRef] [PubMed]

33. Prince, D.C.; Drurey, C.; Zipfel, C.; Hogenhout, S.A. The leucine-rich repeat receptor-like kinase brassinosteroid insensitive1-associated kinase 1 and the cytochrome $\mathrm{p} 450$ phytoalexin deficient 3 contribute to innate immunity to aphids in arabidopsis. Plant Physiol. 2014, 164, 2207-2219. [CrossRef] [PubMed]

34. Park, C.-J.; Ronald, P.C. Cleavage and nuclear localization of the rice xa21 immune receptor. Nat. Commun. 2012, 3, 920. [CrossRef] [PubMed]

35. Zipfel, C.; Robatzek, S.; Navarro, L.; Oakeley, E.J. Bacterial disease resistance in Arabidopsis through flagellin perception. Nature 2004, 428, 764-767. [CrossRef] [PubMed]

36. Kunze, G.; Zipfel, C.; Robatzek, S.; Niehaus, K.; Boller, T.; Felix, G. The N terminus of bacterial elongation factor tu elicits innate immunity in Arabidopsis plants. Plant Cell 2004, 16, 3496-3507. [CrossRef] [PubMed]

37. Gust, A.A.; Biswas, R.; Lenz, H.D.; Rauhut, T.; Ranf, S.; Kemmerling, B.; Götz, F.; Glawischnig, E.; Lee, J.; Felix, G. Bacteria-derived peptidoglycans constitute pathogen-associated molecular patterns triggering innate immunity in Arabidopsis. J. Biol. Chem. 2007, 282, 32338-32348. [CrossRef] [PubMed]

38. Kaku, H.; Nishizawa, Y.; Ishii-Minami, N.; Akimoto-Tomiyama, C.; Dohmae, N.; Takio, K.; Minami, E.; Shibuya, N. Plant cells recognize chitin fragments for defense signaling through a plasma membrane receptor. Proc. Natl. Acad. Sci. USA 2006, 103, 11086-11091. [CrossRef] [PubMed]

39. Ron, M.; Avni, A. The receptor for the fungal elicitor ethylene-inducing xylanase is a member of a resistance-like gene family in tomato. Plant Cell 2004, 16, 1604-1615. [CrossRef] [PubMed]

40. Fliegmann, J.; Mithöfer, A.; Wanner, G.; Ebel, J. An ancient enzyme domain hidden in the putative $\beta$-glucan elicitor receptor of soybean may play an active part in the perception of pathogen-associated molecular patterns during broad host resistance. J. Biol. Chem. 2004, 279, 1132-1140. [CrossRef] [PubMed]

41. Du, J.; Verzaux, E.; Chaparro-Garcia, A.; Bijsterbosch, G.; Keizer, L.P.; Zhou, J.; Liebrand, T.W.; Xie, C.; Govers, F.; Robatzek, S. Elicitin recognition confers enhanced resistance to phytophthora infestans in potato. Nat. Plants 2015, 1, 15034. [CrossRef] [PubMed]

42. Feuillet, C.; Schachermayr, G.; Keller, B. Molecular cloning of a new receptor-like kinase gene encoded at the Lr10 disease resistance locus of wheat. Plant J. 1997, 11, 45-52. [CrossRef] [PubMed]

43. Zhou, H.; Li, S.; Deng, Z.; Wang, X.; Chen, T.; Zhang, J.; Chen, S.; Ling, H.; Zhang, A.; Wang, D. Molecular analysis of three new receptor-like kinase genes from hexaploid wheat and evidence for their participation in the wheat hypersensitive response to stripe rust fungus infection. Plant J. 2007, 52, 420-434. [CrossRef] [PubMed]

44. Jiang, Z.; Ge, S.; Xing, L.; Han, D.; Kang, Z.; Zhang, G.; Wang, X.; Wang, X.; Chen, P.; Cao, A. RLP1.1, a novel wheat receptor-like protein gene, is involved in the defence response against Puccinia striiformis f. sp. tritici. J. Exp. Bot. 2013, 64, 3735-3746. [CrossRef] [PubMed]

45. Brutus, A.; Sicilia, F.; Macone, A.; Cervone, F.; De Lorenzo, G. A domain swap approach reveals a role of the plant wall-associated kinase 1 (WAK1) as a receptor of oligogalacturonides. Proc. Natl. Acad. Sci. USA 2010, 107, 9452-9457. [CrossRef] [PubMed]

46. Choi, J.; Tanaka, K.; Cao, Y.; Qi, Y.; Qiu, J.; Liang, Y.; Lee, S.Y.; Stacey, G. Identification of a plant receptor for extracellular ATP. Science 2014, 343, 290-294. [CrossRef] [PubMed]

47. Lannoo, N.; Van Damme, E.J. Lectin domains at the frontiers of plant defense. Front. Plant Sci. 2014, 5, 397. [CrossRef] [PubMed]

48. Gust, A.A.; Pruitt, R.; Nürnberger, T. Sensing danger: Key to activating plant immunity. Trends Plant Sci. 2017, 22, 779-791. [CrossRef] [PubMed]

49. Lo Presti, L.; Lanver, D.; Schweizer, G.; Tanaka, S.; Liang, L.; Tollot, M.; Zuccaro, A.; Reissmann, S.; Kahmann, R. Fungal effectors and plant susceptibility. Ann. Rev. Plant Biol. 2015, 66, 513-545. [CrossRef] [PubMed]

50. van den Burg, H.A.; Harrison, S.J.; Joosten, M.H.; Vervoort, J.; de Wit, P.J. Cladosporium fulvum Avr4 protects fungal cell walls against hydrolysis by plant chitinases accumulating during infection. Mol. Plant Microbe Interact. 2006, 19, 1420-1430. [CrossRef] [PubMed]

51. Mentlak, T.A.; Kombrink, A.; Shinya, T.; Ryder, L.S.; Otomo, I.; Saitoh, H.; Terauchi, R.; Nishizawa, Y.; Shibuya, N.; Thomma, B.P. Effector-mediated suppression of chitin-triggered immunity by Magnaporthe oryzae is necessary for rice blast disease. Plant Cell 2012, 24, 322-335. [CrossRef] [PubMed] 
52. Takken, F.L.; Goverse, A. How to build a pathogen detector: Structural basis of NB-LRR function. Curr. Opin. Plant Biol. 2012, 15, 375-384. [CrossRef] [PubMed]

53. Michelmore, R.W.; Christopoulou, M.; Caldwell, K.S. Impacts of resistance gene genetics, function, and evolution on a durable future. Ann. Rev. Phytopathol. 2013, 51, 291-319. [CrossRef] [PubMed]

54. Cui, H.; Tsuda, K.; Parker, J.E. Effector-triggered immunity: From pathogen perception to robust defense. Ann. Rev. Plant Biol. 2015, 66, 487-511. [CrossRef] [PubMed]

55. Jacob, F.; Vernaldi, S.; Maekawa, T. Evolution and conservation of plant NLR functions. Front. Immunol. 2013, 4, 297. [CrossRef] [PubMed]

56. Hayashi, N.; Inoue, H.; Kato, T.; Funao, T.; Shirota, M.; Shimizu, T.; Kanamori, H.; Yamane, H.; Hayano-Saito, Y.; Matsumoto, T. Durable panicle blast-resistance gene Pb1 encodes an atypical CC-NBS-LRR protein and was generated by acquiring a promoter through local genome duplication. Plant J. 2010, 64, 498-510. [CrossRef] [PubMed]

57. Wu, C.-H.; Abd-El-Haliem, A.; Bozkurt, T.O.; Belhaj, K.; Terauchi, R.; Vossen, J.H.; Kamoun, S. NLR network mediates immunity to diverse plant pathogens. Proc. Natl. Acad. Sci. USA 2017, 114, 8113-8118. [CrossRef] [PubMed]

58. Wu, C.H.; Belhaj, K.; Bozkurt, T.O.; Birk, M.S.; Kamoun, S. Helper NLR proteins NRC2a/b and NRC3 but not NRC1 are required for PTO-mediated cell death and resistance in Nicotiana benthamiana. New Phytol. 2016, 209, 1344-1352. [CrossRef] [PubMed]

59. Baggs, E.; Dagdas, G.; Krasileva, K. NLR diversity, helpers and integrated domains: Making sense of the NLR identity. Curr. Opin. Plant Biol. 2017, 38, 59-67. [CrossRef] [PubMed]

60. Tran, D.T.; Chung, E.-H.; Habring-Müller, A.; Demar, M.; Schwab, R.; Dangl, J.L.; Weigel, D.; Chae, E. Activation of a plant NLR complex through heteromeric association with an autoimmune risk variant of another NLR. Curr. Biol. 2017, 27, 1148-1160. [CrossRef] [PubMed]

61. Horinouchi, S.; Kito, M.; Nishiyama, M.; Furuya, K.; Hong, S.-K.; Miyake, K.; Beppu, T. Primary structure of AfsR, a global regulatory protein for secondary metabolite formation in Streptomyces coelicolor A3 (2). Gene 1990, 95, 49-56. [CrossRef]

62. Hengartner, M.O.; Horvitz, H.R. Programmed cell death in Caenorhabditis elegans. Curr. Opin. Genet. Dev. 1994, 4, 581-586. [CrossRef]

63. Zou, H.; Henzel, W.J.; Liu, X.; Lutschg, A.; Wang, X. Apaf-1, a human protein homologous to C. elegans CED-4, participates in cytochrome c-dependent activation of caspase-3. Cell 1997, 90, 405-413. [CrossRef]

64. Andersen, E.J.; Ali, S.; Reese, R.N.; Yen, Y.; Neupane, S.; Nepal, M.P. Diversity and evolution of disease resistance genes in barley (Hordeum vulgare L.). Evol. Bioinformat. Online 2016, 12, 99-108. [CrossRef] [PubMed]

65. Marone, D.; Russo, M.A.; Laidò, G.; De Leonardis, A.M.; Mastrangelo, A.M. Plant nucleotide binding site-leucine-rich repeat (NBS-LRR) genes: Active guardians in host defense responses. Int. J. Mol. Sci. 2013, 14, 7302-7326. [CrossRef] [PubMed]

66. Le, T.-N.; Schumann, U.; Smith, N.A.; Tiwari, S.; Au, P.C.K.; Zhu, Q.-H.; Taylor, J.M.; Kazan, K.; Llewellyn, D.J.; Zhang, R. DNA demethylases target promoter transposable elements to positively regulate stress responsive genes in Arabidopsis. Genome Biol. 2014, 15, 458. [CrossRef] [PubMed]

67. Seidl, M.F.; Thomma, B.P. Transposable elements direct the coevolution between plants and microbes. Trends Genet. 2017, 33, 842-851. [CrossRef] [PubMed]

68. Meyers, B.C.; Kozik, A.; Griego, A.; Kuang, H.; Michelmore, R.W. Genome-wide analysis of NBS-LRR-encoding genes in Arabidopsis. Plant Cell Online 2003, 15, 809-834. [CrossRef]

69. Dodds, P.N.; Lawrence, G.J.; Catanzariti, A.-M.; Teh, T.; Wang, C.-I.; Ayliffe, M.A.; Kobe, B.; Ellis, J.G. Direct protein interaction underlies gene-for-gene specificity and coevolution of the flax resistance genes and flax rust avirulence genes. Proc. Natl. Acad. Sci. USA 2006, 103, 8888-8893. [CrossRef] [PubMed]

70. Van Der Biezen, E.A.; Jones, J.D. Plant disease-resistance proteins and the gene-for-gene concept. Trends Biochem. Sci. 1998, 23, 454-456. [CrossRef]

71. van der Hoorn, R.A.; Kamoun, S. From guard to decoy: A new model for perception of plant pathogen effectors. Plant Cell 2008, 20, 2009-2017. [CrossRef] [PubMed]

72. Cesari, S.; Bernoux, M.; Moncuquet, P.; Kroj, T.; Dodds, P.N. A novel conserved mechanism for plant NLR protein pairs: The "integrated decoy" hypothesis. Front. Plant Sci. 2014, 5, 606. [CrossRef] [PubMed] 
73. Wu, C.-H.; Krasileva, K.V.; Banfield, M.J.; Terauchi, R.; Kamoun, S. The “sensor domains" of plant NLR proteins: More than decoys? Front. Plant Sci. 2015, 6, 134. [CrossRef] [PubMed]

74. Kroj, T.; Chanclud, E.; Michel-Romiti, C.; Grand, X.; Morel, J.B. Integration of decoy domains derived from protein targets of pathogen effectors into plant immune receptors is widespread. New Phytol. 2016, 210, 618-626. [CrossRef] [PubMed]

75. Marathe, R.; Dinesh-Kumar, S. Plant defense: One post, multiple guards?! Mol. Cell 2003, 11, $284-286$. [CrossRef]

76. Axtell, M.J.; Staskawicz, B.J. Initiation of RPS2-specified disease resistance in Arabidopsis is coupled to the AvrRpt2-directed elimination of RIN4. Cell 2003, 112, 369-377. [CrossRef]

77. Holt, B.F.; Boyes, D.C.; Ellerström, M.; Siefers, N.; Wiig, A.; Kauffman, S.; Grant, M.R.; Dangl, J.L. An evolutionarily conserved mediator of plant disease resistance gene function is required for normal arabidopsis development. Dev. Cell 2002, 2, 807-817. [CrossRef]

78. Noutoshi, Y.; Ito, T.; Seki, M.; Nakashita, H.; Yoshida, S.; Marco, Y.; Shirasu, K.; Shinozaki, K. A single amino acid insertion in the WRKY domain of the arabidopsis TIR-NBS-LRR-WRKY -type disease resistance protein SLH1 (sensitive to low humidity 1) causes activation of defense responses and hypersensitive cell death. Plant J. 2005, 43, 873-888. [CrossRef] [PubMed]

79. Sarris, P.F.; Duxbury, Z.; Huh, S.U.; Ma, Y.; Segonzac, C.; Sklenar, J.; Derbyshire, P.; Cevik, V.; Rallapalli, G.; Saucet, S.B. A plant immune receptor detects pathogen effectors that target WRKY transcription factors. Cell 2015, 161, 1089-1100. [CrossRef] [PubMed]

80. Le Roux, C.; Huet, G.; Jauneau, A.; Camborde, L.; Trémousaygue, D.; Kraut, A.; Zhou, B.; Levaillant, M.; Adachi, H.; Yoshioka, H. A receptor pair with an integrated decoy converts pathogen disabling of transcription factors to immunity. Cell 2015, 161, 1074-1088. [CrossRef] [PubMed]

81. Cesari, S.; Thilliez, G.; Ribot, C.; Chalvon, V.; Michel, C.; Jauneau, A.; Rivas, S.; Alaux, L.; Kanzaki, H.; Okuyama, Y. The rice resistance protein pair RGA4/RGA5 recognizes the Magnaporthe oryzae effectors AVR-Pia and AVR1-CO39 by direct binding. Plant Cell 2013, 25, 1463-1481. [CrossRef] [PubMed]

82. Césari, S.; Kanzaki, H.; Fujiwara, T.; Bernoux, M.; Chalvon, V.; Kawano, Y.; Shimamoto, K.; Dodds, P.; Terauchi, R.; Kroj, T. The NB-LRR proteins RGA4 and RGA5 interact functionally and physically to confer disease resistance. EMBO J. 2014, 33, 1941-1959. [CrossRef] [PubMed]

83. Casey, L.W.; Lavrencic, P.; Bentham, A.R.; Cesari, S.; Ericsson, D.J.; Croll, T.; Turk, D.; Anderson, P.A.; Mark, A.E.; Dodds, P.N. The CC domain structure from the wheat stem rust resistance protein SR33 challenges paradigms for dimerization in plant NLR proteins. Proc. Natl. Acad. Sci. USA 2016, 113, 12856-12861. [CrossRef] [PubMed]

84. Day, B.; Dahlbeck, D.; Staskawicz, B.J. NDR1 interaction with RIN4 mediates the differential activation of multiple disease resistance pathways in Arabidopsis. Plant Cell 2006, 18, 2782-2791. [CrossRef] [PubMed]

85. Knepper, C.; Savory, E.A.; Day, B. The role of NDR1 in pathogen perception and plant defense signaling. Plant Signal. Behav. 2011, 6, 1114-1116. [CrossRef] [PubMed]

86. Wiermer, M.; Feys, B.J.; Parker, J.E. Plant immunity: The EDS1 regulatory node. Curr. Opin. Plant Biol. 2005, 8, 383-389. [CrossRef] [PubMed]

87. Engelhardt, S.; Boevink, P.C.; Armstrong, M.R.; Ramos, M.B.; Hein, I.; Birch, P.R. Relocalization of late blight resistance protein $\mathrm{R} 3 \mathrm{~A}$ to endosomal compartments is associated with effector recognition and required for the immune response. Plant Cell 2012, 24, 5142-5158. [CrossRef] [PubMed]

88. Shen, Q.-H.; Saijo, Y.; Mauch, S.; Biskup, C.; Bieri, S.; Keller, B.; Seki, H.; Ülker, B.; Somssich, I.E.; Schulze-Lefert, P. Nuclear activity of MLA immune receptors links isolate-specific and basal disease-resistance responses. Science 2007, 315, 1098-1103. [CrossRef] [PubMed]

89. Bozkurt, T.O.; Schornack, S.; Win, J.; Shindo, T.; Ilyas, M.; Oliva, R.; Cano, L.M.; Jones, A.M.; Huitema, E.; van der Hoorn, R.A. Phytophthora infestans effector AVRblb2 prevents secretion of a plant immune protease at the haustorial interface. Proc. Natl. Acad. Sci. USA 2011, 108, 20832-20837. [CrossRef] [PubMed]

90. Nomura, K.; DebRoy, S.; Lee, Y.H.; Pumplin, N.; Jones, J.; He, S.Y. A bacterial virulence protein suppresses host innate immunity to cause plant disease. Science 2006, 313, 220-223. [CrossRef] [PubMed]

91. Chaparro-Garcia, A.; Schwizer, S.; Sklenar, J.; Yoshida, K.; Petre, B.; Bos, J.I.; Schornack, S.; Jones, A.M.; Bozkurt, T.O.; Kamoun, S. Phytophthora infestans RXRL-WY effector AVR3a associates with dynamin-related protein 2 required for endocytosis of the plant pattern recognition receptor FLS2. PLoS ONE 2015, 10, e0137071. [CrossRef] [PubMed] 
92. Shi, G.; Zhang, Z.; Friesen, T.L.; Raats, D.; Fahima, T.; Brueggeman, R.S.; Lu, S.; Trick, H.N.; Liu, Z.; Chao, W. The hijacking of a receptor kinase-driven pathway by a wheat fungal pathogen leads to disease. Sci. Adv. 2016, 2, e1600822. [CrossRef] [PubMed]

93. Liu, Z.; Gao, Y.; Kim, Y.M.; Faris, J.D.; Shelver, W.L.; Wit, P.J.; Xu, S.S.; Friesen, T.L. SnTox1, a Parastagonospora nodorum necrotrophic effector, is a dual-function protein that facilitates infection while protecting from wheat-produced chitinases. New Phytol. 2016, 211, 1052-1064. [CrossRef] [PubMed]

94. Ciuffetti, L.M.; Manning, V.A.; Pandelova, I.; Betts, M.F.; Martinez, J.P. Host-selective toxins, Ptr toxA and Ptr toxB, as necrotrophic effectors in the Pyrenophora tritici-repentis-wheat interaction. New Phytol. 2010, 187, 911-919. [CrossRef] [PubMed]

95. Liu, Z.; Zurn, J.D.; Kariyawasam, G.; Faris, J.D.; Shi, G.; Hansen, J.; Rasmussen, J.B.; Acevedo, M. Inverse gene-for-gene interactions contribute additively to tan spot susceptibility in wheat. Theor. Appl. Genet. 2017, 130, 1267-1276. [CrossRef] [PubMed]

96. Faris, J.D.; Zhang, Z.; Lu, H.; Lu, S.; Reddy, L.; Cloutier, S.; Fellers, J.P.; Meinhardt, S.W.; Rasmussen, J.B.; $\mathrm{Xu}$, S.S. A unique wheat disease resistance-like gene governs effector-triggered susceptibility to necrotrophic pathogens. Proc. Natl. Acad. Sci. USA 2010, 107, 13544-13549. [CrossRef] [PubMed]

97. Manning, V.A.; Chu, A.L.; Steeves, J.E.; Wolpert, T.J.; Ciuffetti, L.M. A host-selective toxin of Pyrenophora tritici-repentis, Ptr toxA, induces photosystem changes and reactive oxygen species accumulation in sensitive wheat. Mol. Plant Microbe Interact. 2009, 22, 665-676. [CrossRef] [PubMed]

98. Ichimura, K.; Shinozaki, K.; Tena, G.; Sheen, J.; Henry, Y.; Champion, A.; Kreis, M.; Zhang, S.; Hirt, H.; Wilson, C. Mitogen-activated protein kinase cascades in plants: A new nomenclature. Trends Plant Sci. 2002, 7, 301-308.

99. Zipfel, C.; Kunze, G.; Chinchilla, D.; Caniard, A.; Jones, J.D.; Boller, T.; Felix, G. Perception of the bacterial PAMP EF-TU by the receptor EFR restricts Agrobacterium-mediated transformation. Cell 2006, 125, 749-760. [CrossRef] [PubMed]

100. Chinchilla, D.; Zipfel, C.; Robatzek, S.; Kemmerling, B.; Nürnberger, T.; Jones, J.D.; Felix, G.; Boller, T. A flagellin-induced complex of the receptor FLS2 and BAK1 initiates plant defence. Nature 2007, 448, 497-500. [CrossRef] [PubMed]

101. Galletti, R.; Ferrari, S.; De Lorenzo, G. Arabidopsis MPK3 and MPK6 play different roles in basal and oligogalacturonide-or flagellin-induced resistance against Botrytis cinerea. Plant Physiol. 2011, 157, 804-814. [CrossRef] [PubMed]

102. Kohorn, B.D.; Kohorn, S.L.; Todorova, T.; Baptiste, G.; Stansky, K.; McCullough, M. A dominant allele of Arabidopsis pectin-binding wall-associated kinase induces a stress response suppressed by MPK6 but not MPK3 mutations. Mol. Plant 2012, 5, 841-851. [CrossRef] [PubMed]

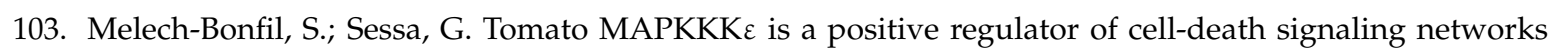
associated with plant immunity. Plant J. 2010, 64, 379-391. [CrossRef] [PubMed]

104. del Pozo, O.; Pedley, K.F.; Martin, G.B. MAPKKK $\alpha$ is a positive regulator of cell death associated with both plant immunity and disease. EMBO J. 2004, 23, 3072-3082. [CrossRef] [PubMed]

105. Oh, C.-S.; Martin, G.B. Effector-triggered immunity mediated by the Pto kinase. Trends Plant Sci. 2011, 16, 132-140. [CrossRef] [PubMed]

106. Frye, C.A.; Tang, D.; Innes, R.W. Negative regulation of defense responses in plants by a conserved MAPKK kinase. Proc. Natl. Acad. Sci. USA 2001, 98, 373-378. [CrossRef] [PubMed]

107. Zhang, J.; Shao, F.; Li, Y.; Cui, H.; Chen, L.; Li, H.; Zou, Y.; Long, C.; Lan, L.; Chai, J. A Pseudomonas syringae effector inactivates MAPKs to suppress PAMP-induced immunity in plants. Cell Host Microbe 2007, 1, 175-185. [CrossRef] [PubMed]

108. Temple, B.R.; Jones, A.M. The plant heterotrimeric G-protein complex. Annu. Rev. Plant Biol. 2007, 58, 249-266. [CrossRef] [PubMed]

109. Trusov, Y.; Botella, J.R. Plant G-proteins come of age: Breaking the bond with animal models. Front. Chem. 2016, 4, 24. [CrossRef] [PubMed]

110. Temple, B.R.; Jones, C.D.; Jones, A.M. Evolution of a signaling nexus constrained by protein interfaces and conformational states. PLoS Comput. Biol. 2010, 6, e1000962. [CrossRef] [PubMed]

111. Jones, A.M.; Assmann, S.M. Plants: The latest model system for G-protein research. EMBO Rep. 2004, 5, 572-578. [CrossRef] [PubMed] 
112. Park, H.J.; Kim, W.-Y.; Park, H.C.; Lee, S.Y.; Bohnert, H.J.; Yun, D.-J. Sumo and sumoylation in plants. Mol. Cells 2011, 32, 305-316. [CrossRef] [PubMed]

113. Poovaiah, B.; Du, L.; Wang, H.; Yang, T. Recent advances in calcium/calmodulin-mediated signaling with an emphasis on plant-microbe interactions. Plant Physiol. 2013, 163, 531-542. [CrossRef] [PubMed]

114. Reddy, A.S.; Ali, G.S.; Celesnik, H.; Day, I.S. Coping with stresses: Roles of calcium-and calcium/calmodulin-regulated gene expression. Plant Cell 2011, 23, 2010-2032. [CrossRef] [PubMed]

115. Takahashi, F.; Mizoguchi, T.; Yoshida, R.; Ichimura, K.; Shinozaki, K. Calmodulin-dependent activation of MAP kinase for ROS homeostasis in arabidopsis. Mol. Cell 2011, 41, 649-660. [CrossRef] [PubMed]

116. Gao, X.; Chen, X.; Lin, W.; Chen, S.; Lu, D.; Niu, Y.; Li, L.; Cheng, C.; McCormack, M.; Sheen, J. Bifurcation of arabidopsis NLR immune signaling via $\mathrm{Ca}^{2+}$-dependent protein kinases. PLoS Pathog. 2013, 9, e1003127. [CrossRef] [PubMed]

117. Tsuda, K.; Mine, A.; Bethke, G.; Igarashi, D.; Botanga, C.J.; Tsuda, Y.; Glazebrook, J.; Sato, M.; Katagiri, F. Dual regulation of gene expression mediated by extended MAPK activation and salicylic acid contributes to robust innate immunity in Arabidopsis thaliana. PLoS Genet. 2013, 9, e1004015. [CrossRef] [PubMed]

118. Vlot, A.C.; Dempsey, D.M.A.; Klessig, D.F. Salicylic acid, a multifaceted hormone to combat disease. Ann. Rev. Phytopathol. 2009, 47, 177-206. [CrossRef] [PubMed]

119. Aarts, N.; Metz, M.; Holub, E.; Staskawicz, B.J.; Daniels, M.J.; Parker, J.E. Different requirements for EDS1 and NDR1 by disease resistance genes define at least two R gene-mediated signaling pathways in Arabidopsis. Proc. Natl. Acad. Sci. USA 1998, 95, 10306-10311. [CrossRef] [PubMed]

120. Century, K.S.; Shapiro, A.D.; Repetti, P.P.; Dahlbeck, D.; Holub, E.; Staskawicz, B.J. NDR1, a pathogen-induced component required for arabidopsis disease resistance. Science 1997, 278, 1963-1965. [CrossRef] [PubMed]

121. Tada, Y.; Spoel, S.H.; Pajerowska-Mukhtar, K.; Mou, Z.; Song, J.; Wang, C.; Zuo, J.; Dong, X. Plant immunity requires conformational charges of NPR1 via S-nitrosylation and thioredoxins. Science 2008, 321, 952-956. [CrossRef] [PubMed]

122. Lorang, J.; Kidarsa, T.; Bradford, C.; Gilbert, B.; Curtis, M.; Tzeng, S.-C.; Maier, C.; Wolpert, T. Tricking the guard: Exploiting plant defense for disease susceptibility. Science 2012, 338, 659-662. [CrossRef] [PubMed]

123. Geraats, B.P.; Bakker, P.A.; Lawrence, C.B.; Achuo, E.A.; Höfte, M.; Van Loon, L. Ethylene-insensitive tobacco shows differentially altered susceptibility to different pathogens. Phytopathology 2003, 93, 813-821. [CrossRef] [PubMed]

124. Vijayan, P.; Shockey, J.; Lévesque, C.A.; Cook, R.J. A role for jasmonate in pathogen defense of arabidopsis. Proc. Natl. Acad. Sci. USA 1998, 95, 7209-7214. [CrossRef] [PubMed]

125. Thomma, B.P.; Penninckx, I.A.; Cammue, B.P.; Broekaert, W.F. The complexity of disease signaling in arabidopsis. Curr. Opin. Immunol. 2001, 13, 63-68. [CrossRef]

126. McConn, M.; Creelman, R.A.; Bell, E.; Mullet, J.E. Jasmonate is essential for insect defense in arabidopsis. Proc. Natl. Acad. Sci. USA 1997, 94, 5473-5477. [CrossRef] [PubMed]

127. Ruther, J.; Kleier, S. Plant-plant signaling: Ethylene synergizes volatile emission in Zea mays induced by exposure to (Z)-3-hexen-1-ol. J. Chem. Ecol. 2005, 31, 2217-2222. [CrossRef] [PubMed]

128. Schmelz, E.A.; Alborn, H.T.; Tumlinson, J.H. Synergistic interactions between volicitin, jasmonic acid and ethylene mediate insect-induced volatile emission in Zea mays. Physiol. Plant. 2003, 117, 403-412. [CrossRef] [PubMed]

129. Chung, S.H.; Rosa, C.; Scully, E.D.; Peiffer, M.; Tooker, J.F.; Hoover, K.; Luthe, D.S.; Felton, G.W. Herbivore exploits orally secreted bacteria to suppress plant defenses. Proc. Natl. Acad. Sci. USA 2013, 110, 15728-15733. [CrossRef] [PubMed]

130. Denoux, C.; Galletti, R.; Mammarella, N.; Gopalan, S.; Werck, D.; De Lorenzo, G.; Ferrari, S.; Ausubel, F.M.; Dewdney, J. Activation of defense response pathways by OGs and Flg22 elicitors in Arabidopsis seedlings. Mol. Plant 2008, 1, 423-445. [CrossRef] [PubMed]

131. Tsuda, K.; Somssich, I.E. Transcriptional networks in plant immunity. New Phytol. 2015, $206,932-947$. [CrossRef] [PubMed]

132. Kim, J.-G.; Stork, W.; Mudgett, M.B. Xanthomonas type III effector XopD desumoylates tomato transcription factor SIERF4 to suppress ethylene responses and promote pathogen growth. Cell Host Microbe 2013, 13, 143-154. [CrossRef] [PubMed]

133. Pieterse, C.M.; Leon-Reyes, A.; Van der Ent, S.; Van Wees, S.C. Networking by small-molecule hormones in plant immunity. Nat. Chem. Biol. 2009, 5, 308-316. [CrossRef] [PubMed] 
134. Ton, J.; Flors, V.; Mauch-Mani, B. The multifaceted role of ABA in disease resistance. Trends Plant Sci. 2009, 14, 310-317. [CrossRef] [PubMed]

135. Asselbergh, B.; De Vleesschauwer, D.; Höfte, M. Global switches and fine-tuning-ABA modulates plant pathogen defense. Mol. Plant Microbe Interact. 2008, 21, 709-719. [CrossRef] [PubMed]

136. Lind, C.; Dreyer, I.; López-Sanjurjo, E.J.; von Meyer, K.; Ishizaki, K.; Kohchi, T.; Lang, D.; Zhao, Y.; Kreuzer, I.; Al-Rasheid, K.A. Stomatal guard cells co-opted an ancient ABA-dependent desiccation survival system to regulate stomatal closure. Curr. Biol. 2015, 25, 928-935. [CrossRef] [PubMed]

137. Melotto, M.; Underwood, W.; He, S.Y. Role of stomata in plant innate immunity and foliar bacterial diseases. Annu. Rev. Phytopathol. 2008, 46, 101-122. [CrossRef] [PubMed]

138. Barth, C.; Moeder, W.; Klessig, D.F.; Conklin, P.L. The timing of senescence and response to pathogens is altered in the ascorbate-deficient arabidopsis mutant vitamin C-1. Plant Physiol. 2004, 134, 1784-1792. [CrossRef] [PubMed]

139. Pavet, V.; Olmos, E.; Kiddle, G.; Mowla, S.; Kumar, S.; Antoniw, J.; Alvarez, M.E.; Foyer, C.H. Ascorbic acid deficiency activates cell death and disease resistance responses in Arabidopsis. Plant Physiol. 2005, 139, 1291-1303. [CrossRef] [PubMed]

140. Coppola, M.; Cascone, P.; Madonna, V.; Lelio, I.; Esposito, F.; Avitabile, C.; Romanelli, A.; Guerrieri, E.; Vitiello, A.; Pennacchio, F. Plant-to-plant communication triggered by systemin primes anti-herbivore resistance in tomato. Sci. Rep. 2017, 7, 15522. [CrossRef] [PubMed]

141. Qiu, J.L.; Fiil, B.K.; Petersen, K.; Nielsen, H.B.; Botanga, C.J.; Thorgrimsen, S.; Palma, K.; Suarez-Rodriguez, M.C.; Sandbech-Clausen, S.; Lichota, J. Arabidopsis MAP kinase 4 regulates gene expression through transcription factor release in the nucleus. EMBO J. 2008, 27, 2214-2221. [CrossRef] [PubMed]

142. Lu, J.; Ju, H.; Zhou, G.; Zhu, C.; Erb, M.; Wang, X.; Wang, P.; Lou, Y. An EAR-motif-containing ERF transcription factor affects herbivore-induced signaling, defense and resistance in rice. Plant J. 2011, 68, 583-596. [CrossRef] [PubMed]

143. Zhao, Y.; Wei, T.; Yin, K.Q.; Chen, Z.; Gu, H.; Qu, L.J.; Qin, G. Arabidopsis RAP2.2 plays an important role in plant resistance to Botrytis cinerea and ethylene responses. New Phytol. 2012, 195, 450-460. [CrossRef] [PubMed]

144. Moffat, C.S.; Ingle, R.A.; Wathugala, D.L.; Saunders, N.J.; Knight, H.; Knight, M.R. ERF5 and ERF6 play redundant roles as positive regulators of JA/Et-mediated defense against Botrytis cinerea in Arabidopsis. PLoS ONE 2012, 7, e35995. [CrossRef] [PubMed]

145. Meng, X.; Xu, J.; He, Y.; Yang, K.-Y.; Mordorski, B.; Liu, Y.; Zhang, S. Phosphorylation of an ERF transcription factor by Arabidopsis MPK3/MPK6 regulates plant defense gene induction and fungal resistance. Plant Cell 2013, 25, 1126-1142. [CrossRef] [PubMed]

146. Woldemariam, M.G.; Dinh, S.T.; Oh, Y.; Gaquerel, E.; Baldwin, I.T.; Galis, I. NaMYC2 transcription factor regulates a subset of plant defense responses in Nicotiana attenuata. BMC Plant Biol. 2013, 13, 73. [CrossRef] [PubMed]

147. Okada, A.; Okada, K.; Miyamoto, K.; Koga, J.; Shibuya, N.; Nojiri, H.; Yamane, H. OsTGAP1, a bZIP transcription factor, coordinately regulates the inductive production of diterpenoid phytoalexins in rice. J. Biol. Chem. 2009, 284, 26510-26518. [CrossRef] [PubMed]

148. Seo, P.J.; Kim, M.J.; Park, J.Y.; Kim, S.Y.; Jeon, J.; Lee, Y.H.; Kim, J.; Park, C.M. Cold activation of a plasma membrane-tethered NAC transcription factor induces a pathogen resistance response in Arabidopsis. Plant $J$. 2010, 61, 661-671. [CrossRef] [PubMed]

149. Wu, Y.; Deng, Z.; Lai, J.; Zhang, Y.; Yang, C.; Yin, B.; Zhao, Q.; Zhang, L.; Li, Y.; Yang, C. Dual function of Arabidopsis ATAF1 in abiotic and biotic stress responses. Cell Res. 2009, 19, 1279-1290. [CrossRef] [PubMed]

150. Lorenzo, O.; Chico, J.M.; Sánchez-Serrano, J.J.; Solano, R. JASMONATE-INSENSITIVE1 encodes a MYC transcription factor essential to discriminate between different jasmonate-regulated defense responses in Arabidopsis. Plant Cell 2004, 16, 1938-1950. [CrossRef] [PubMed]

151. Jensen, M.K.; Rung, J.H.; Gregersen, P.L.; Gjetting, T.; Fuglsang, A.T.; Hansen, M.; Joehnk, N.; Lyngkjaer, M.F.; Collinge, D.B. The HvNAC6 transcription factor: A positive regulator of penetration resistance in barley and Arabidopsis. Plant Mol. Biol. 2007, 65, 137-150. [CrossRef] [PubMed]

152. Rinerson, C.I.; Rabara, R.C.; Tripathi, P.; Shen, Q.J.; Rushton, P.J. The evolution of WRKY transcription factors. BMC Plant Biol. 2015, 15, 66. [CrossRef] [PubMed] 
153. Chen, L.; Zhang, L.; Li, D.; Wang, F.; Yu, D. WRKY8 transcription factor functions in the TMV-cg defense response by mediating both abscisic acid and ethylene signaling in Arabidopsis. Proc. Natl. Acad. Sci. USA 2013, 110, E1963-E1971. [CrossRef] [PubMed]

154. Li, G.; Meng, X.; Wang, R.; Mao, G.; Han, L.; Liu, Y.; Zhang, S. Dual-level regulation of ACC synthase activity by MPK3/MPK6 cascade and its downstream WRKY transcription factor during ethylene induction in arabidopsis. PLoS Genet. 2012, 8, e1002767. [CrossRef] [PubMed]

155. Mao, G.; Meng, X.; Liu, Y.; Zheng, Z.; Chen, Z.; Zhang, S. Phosphorylation of a WRKY transcription factor by two pathogen-responsive MAPKks drives phytoalexin biosynthesis in Arabidopsis. Plant Cell 2011, 23, 1639-1653. [CrossRef] [PubMed]

156. Chang, C.; Yu, D.; Jiao, J.; Jing, S.; Schulze-Lefert, P.; Shen, Q.-H. Barley MLA immune receptors directly interfere with antagonistically acting transcription factors to initiate disease resistance signaling. Plant Cell 2013, 25, 1158-1173. [CrossRef] [PubMed]

157. Inoue, H.; Hayashi, N.; Matsushita, A.; Xinqiong, L.; Nakayama, A.; Sugano, S.; Jiang, C.-J.; Takatsuji, H. Blast resistance of CC-NB-LRR protein $\mathrm{Pb} 1$ is mediated by WRKY45 through protein-protein interaction. Proc. Natl. Acad. Sci. USA 2013, 110, 9577-9582. [CrossRef] [PubMed]

158. Peng, Y.; Bartley, L.E.; Chen, X.; Dardick, C.; Chern, M.; Ruan, R.; Canlas, P.E.; Ronald, P.C. OsWRKY62 is a negative regulator of basal and Xa21-mediated defense against Xanthomonas oryzae pv. oryzae in rice. Mol. Plant 2008, 1, 446-458. [CrossRef] [PubMed]

159. Tao, Z.; Liu, H.; Qiu, D.; Zhou, Y.; Li, X.; Xu, C.; Wang, S. A pair of allelic WRKY genes play opposite roles in rice-bacteria interactions. Plant Physiol. 2009, 151, 936-948. [CrossRef] [PubMed]

160. Lozano-Durán, R.; Macho, A.P.; Boutrot, F.; Segonzac, C.; Somssich, I.E.; Zipfel, C. The transcriptional regulator BZR1 mediates trade-off between plant innate immunity and growth. Elife 2013, 2, e00983. [CrossRef] [PubMed]

161. Wang, J.; Tao, F.; Tian, W.; Guo, Z.; Chen, X.; Xu, X.; Shang, H.; Hu, X. The wheat WRKY transcription factors TaWRKY49 and TaWRKY62 confer differential high-temperature seedling-plant resistance to Puccinia striiformis f. sp. tritici. PLoS ONE 2017, 12, e0181963. [CrossRef] [PubMed]

162. McLellan, H.; Boevink, P.C.; Armstrong, M.R.; Pritchard, L.; Gomez, S.; Morales, J.; Whisson, S.C.; Beynon, J.L.; Birch, P.R. An RXLR effector from Phytophthora infestans prevents re-localisation of two plant NAC transcription factors from the endoplasmic reticulum to the nucleus. PLoS Pathog. 2013, 9, e1003670. [CrossRef] [PubMed]

163. Block, A.; Toruño, T.Y.; Elowsky, C.G.; Zhang, C.; Steinbrenner, J.; Beynon, J.; Alfano, J.R. The Pseudomonas syringae type III effector HopD1 suppresses effector-triggered immunity, localizes to the endoplasmic reticulum, and targets the Arabidopsis transcription factor NTL9. New Phytol. 2014, 201, 1358-1370. [CrossRef] [PubMed]

164. Wang, X.; Goregaoker, S.P.; Culver, J.N. Interaction of the Tobacco mosaic virus replicase protein with a NAC domain transcription factor is associated with the suppression of systemic host defenses. J. Virol. 2009, 83, 9720-9730. [CrossRef] [PubMed]

165. Schornack, S.; Moscou, M.J.; Ward, E.R.; Horvath, D.M. Engineering plant disease resistance based on tal effectors. Ann. Rev. Phytopathol. 2013, 51, 383-406. [CrossRef] [PubMed]

166. Tian, D.; Wang, J.; Zeng, X.; Gu, K.; Qiu, C.; Yang, X.; Zhou, Z.; Goh, M.; Luo, Y.; Murata-Hori, M. The rice TAL effector-dependent resistance protein XA10 triggers cell death and calcium depletion in the endoplasmic reticulum. Plant Cell 2014, 26, 497-515. [CrossRef] [PubMed]

167. Römer, P.; Hahn, S.; Jordan, T.; Strauß, T.; Bonas, U.; Lahaye, T. Plant pathogen recognition mediated by promoter activation of the pepper Bs3 resistance gene. Science 2007, 318, 645-648. [CrossRef] [PubMed]

168. Jaskiewicz, M.; Conrath, U.; Peterhänsel, C. Chromatin modification acts as a memory for systemic acquired resistance in the plant stress response. EMBO Rep. 2011, 12, 50-55. [CrossRef] [PubMed]

169. Holeski, L.M.; Jander, G.; Agrawal, A.A. Transgenerational defense induction and epigenetic inheritance in plants. Trends Ecol. Evol. 2012, 27, 618-626. [CrossRef] [PubMed]

170. Dowen, R.H.; Pelizzola, M.; Schmitz, R.J.; Lister, R.; Dowen, J.M.; Nery, J.R.; Dixon, J.E.; Ecker, J.R. Widespread dynamic DNA methylation in response to biotic stress. Proc. Natl. Acad. Sci. USA 2012, 109, E2183-E2191. [CrossRef] [PubMed]

171. López Sánchez, A.; Stassen, J.H.; Furci, L.; Smith, L.M.; Ton, J. The role of DNA (de)methylation in immune responsiveness of Arabidopsis. Plant J. 2016, 88, 361-374. [CrossRef] [PubMed] 
172. Choi, S.M.; Song, H.R.; Han, S.K.; Han, M.; Kim, C.Y.; Park, J.; Lee, Y.H.; Jeon, J.S.; Noh, Y.S.; Noh, B. HDA19 is required for the repression of salicylic acid biosynthesis and salicylic acid-mediated defense responses in Arabidopsis. Plant J. 2012, 71, 135-146. [CrossRef] [PubMed]

173. Kim, K.-C.; Lai, Z.; Fan, B.; Chen, Z. Arabidopsis WRKY38 and WRKY62 transcription factors interact with histone deacetylase 19 in basal defense. Plant Cell 2008, 20, 2357-2371. [CrossRef] [PubMed]

174. Mosher, R.A.; Durrant, W.E.; Wang, D.; Song, J.; Dong, X. A comprehensive structure-function analysis of Arabidopsis SNI1 defines essential regions and transcriptional repressor activity. Plant Cell 2006, 18, 1750-1765. [CrossRef] [PubMed]

175. Burketova, L.; Trda, L.; Ott, P.G.; Valentova, O. Bio-based resistance inducers for sustainable plant protection against pathogens. Biotechnol. Adv. 2015, 33, 994-1004. [CrossRef] [PubMed]

176. Walters, D.R.; Paterson, L. Parents lend a helping hand to their offspring in plant defence. Biol. Lett. 2012, 8 , 871-873. [CrossRef] [PubMed]

177. Ameye, M.; Audenaert, K.; De Zutter, N.; Steppe, K.; Van Meulebroek, L.; Vanhaecke, L.; De Vleesschauwer, D.; Haesaert, G.; Smagghe, G. Priming of wheat with the green leaf volatile Z-3-hexenyl acetate enhances defense against Fusarium graminearum but boosts deoxynivalenol production. Plant Physiol. 2015, 167, 1671-1684. [CrossRef] [PubMed]

178. Beachy, R.N. Mechanisms and applications of pathogen-derived resistance in transgenic plants. Curr. Opin. Biotechnol. 1997, 8, 215-220. [CrossRef]

179. Abel, P.P.; Nelson, R.S.; De, B.; Hoffmann, N.; Rogers, S.G.; Fraley, R.T.; Beachy, R.N. Delay of disease development in transgenic plants that express the tobacco mosaic virus coat protein gene. Science 1986, 232, 738-744. [CrossRef] [PubMed]

180. Namba, S.; Ling, K.; Gonsalves, C.; Slightom, J.L.; Gonsalves, D. Protection of transgenic plants expressing the coat protein gene of watermelon mosaic virus ii or zucchini yellow mosaic virus against six potyviruses. Phytopathology 1992, 82, 940-946. [CrossRef]

181. Navarro, L.; Jay, F.; Nomura, K.; He, S.Y.; Voinnet, O. Suppression of the microRNA pathway by bacterial effector proteins. Science 2008, 321, 964-967. [CrossRef] [PubMed]

182. Qiao, Y.; Liu, L.; Xiong, Q.; Flores, C.; Wong, J.; Shi, J.; Wang, X.; Liu, X.; Xiang, Q.; Jiang, S. Oomycete pathogens encode RNA silencing suppressors. Nat. Genet. 2013, 45, 330-333. [CrossRef] [PubMed]

183. Pumplin, N.; Voinnet, O. RNA silencing suppression by plant pathogens: Defence, counter-defence and counter-counter-defence. Nat. Rev. Microbiol. 2013, 11, 745-760. [CrossRef] [PubMed]

184. Cruz, L.F.; Rupp, J.L.S.; Trick, H.N.; Fellers, J.P. Stable resistance to Wheat streak mosaic virus in wheat mediated by RNAi. In Vitro Cell. Dev. Biol. Plant 2014, 50, 665-672. [CrossRef]

185. Tian, B.; Li, J.; Oakley, T.R.; Todd, T.C.; Trick, H.N. Host-derived artificial microRNA as an alternative method to improve soybean resistance to soybean cyst nematode. Genes 2016, 7, 122. [CrossRef] [PubMed]

186. Zhai, J.; Jeong, D.-H.; De Paoli, E.; Park, S.; Rosen, B.D.; Li, Y.; González, A.J.; Yan, Z.; Kitto, S.L.; Grusak, M.A. MicroRNAs as master regulators of the plant NB-LRR defense gene family via the production of phased, trans-acting siRNAs. Genes Dev. 2011, 25, 2540-2553. [CrossRef] [PubMed]

187. Li, F.; Pignatta, D.; Bendix, C.; Brunkard, J.O.; Cohn, M.M.; Tung, J.; Sun, H.; Kumar, P.; Baker, B. MicroRNA regulation of plant innate immune receptors. Proc. Natl. Acad. Sci. USA 2012, 109, 1790-1795. [CrossRef] [PubMed]

188. Li, Y.; Zhao, S.-L.; Li, J.-L.; Hu, X.-H.; Wang, H.; Cao, X.-L.; Xu, Y.-J.; Zhao, Z.-X.; Xiao, Z.-Y.; Yang, N. Osa-miR169 negatively regulates rice immunity against the blast fungus Magnaporthe oryzae. Front. Plant Sci. 2017, 8, 2. [CrossRef] [PubMed]

189. Yang, S.; Tang, F.; Zhu, H. Alternative splicing in plant immunity. Int. J. Mol. Sci. 2014, 15, $10424-10445$. [CrossRef] [PubMed]

190. Tsuchiya, T.; Eulgem, T. An alternative polyadenylation mechanism coopted to the Arabidopsis RPP7 gene through intronic retrotransposon domestication. Proc. Natl. Acad. Sci. USA 2013, 110, E3535-E3543. [CrossRef] [PubMed]

191. Sela, H.; Spiridon, L.N.; Petrescu, A.J.; Akerman, M.; Mandel-Gutfreund, Y.; Nevo, E.; Loutre, C.; Keller, B.; Schulman, A.H.; Fahima, T. Ancient diversity of splicing motifs and protein surfaces in the wild emmer wheat (Triticum dicoccoides) LR10 coiled coil (CC) and leucine-rich repeat (LRR) domains. Mol. Plant Pathol. 2012, 13, 276-287. [CrossRef] [PubMed] 
192. Saintenac, C.; Zhang, W.; Salcedo, A.; Rouse, M.N.; Trick, H.N.; Akhunov, E.; Dubcovsky, J. Identification of wheat gene Sr35 that confers resistance to Ug99 stem rust race group. Science 2013, 341, 783-786. [CrossRef] [PubMed]

193. Halterman, D.A.; Wei, F.; Wise, R.P. Powdery mildew-induced Mla mRNAs are alternatively spliced and contain multiple upstream open reading frames. Plant Physiol. 2003, 131, 558-567. [CrossRef] [PubMed]

194. Halterman, D.; Zhou, F.; Wei, F.; Wise, R.P.; Schulze-Lefert, P. The MLA6 coiled-coil, NBS-LRR protein confers AvrMla6-dependent resistance specificity to Blumeria graminis f. sp. hordei in barley and wheat. Plant J. 2001, 25, 335-348. [CrossRef] [PubMed]

195. Wang, M.; Weiberg, A.; Dellota, E. Jr.; Yamane, D.; Jin, H. Botrytis small RNA Bc-siR37 suppresses plant defense genes by cross-kingdom RNAi. RNA Biol. 2017, 14, 421-428. [CrossRef] [PubMed]

196. Weiberg, A.; Wang, M.; Lin, F.-M.; Zhao, H.; Zhang, Z.; Kaloshian, I.; Huang, H.-D.; Jin, H. Fungal small RNAs suppress plant immunity by hijacking host RNA interference pathways. Science 2013, 342, 118-123. [CrossRef] [PubMed]

197. Qiao, Y.; Shi, J.; Zhai, Y.; Hou, Y.; Ma, W. Phytophthora effector targets a novel component of small RNA pathway in plants to promote infection. Proc. Natl. Acad. Sci. USA 2015, 112, 5850-5855. [CrossRef] [PubMed]

198. Sugawara, T.; Trifonova, E.A.; Kochetov, A.V.; Kanayama, Y. Expression of an extracellular ribonuclease gene increases resistance to cucumber mosaic virus in tobacco. BMC Plant Biol. 2016, 16, 246. [CrossRef] [PubMed]

199. Galiana, E.; Bonnet, P.; Conrod, S.; Keller, H.; Panabières, F.; Ponchet, M.; Poupet, A.; Ricci, P. RNase activity prevents the growth of a fungal pathogen in tobacco leaves and increases upon induction of systemic acquired resistance with elicitin. Plant Physiol. 1997, 115, 1557-1567. [CrossRef] [PubMed]

200. Hugot, K.; Ponchet, M.; Marais, A.; Ricci, P.; Galiana, E. A tobacco S-like RNase inhibits hyphal elongation of plant pathogens. Mol. Plant Microbe Interact. 2002, 15, 243-250. [CrossRef] [PubMed]

201. Filipenko, E.; Kochetov, A.; Kanayama, Y.; Malinovsky, V.; Shumny, V. PR-proteins with ribonuclease activity and plant resistance against pathogenic fungi. Russian J. Genet. Appl. Res. 2013, 3, 474-480. [CrossRef]

202. Caporale, C.; Di Berardino, I.; Leonardi, L.; Bertini, L.; Cascone, A.; Buonocore, V.; Caruso, C. Wheat pathogenesis-related proteins of class 4 have ribonuclease activity. FEBS Lett. 2004, 575, 71-76. [CrossRef] [PubMed]

203. Passardi, F.; Cosio, C.; Penel, C.; Dunand, C. Peroxidases have more functions than a swiss army knife. Plant Cell Rep. 2005, 24, 255-265. [CrossRef] [PubMed]

204. Almagro, L.; Gómez Ros, L.; Belchi-Navarro, S.; Bru, R.; Ros Barceló, A.; Pedreno, M. Class III peroxidases in plant defence reactions. J. Exp. Bot. 2008, 60, 377-390. [CrossRef] [PubMed]

205. Kadota, Y.; Sklenar, J.; Derbyshire, P.; Stransfeld, L.; Asai, S.; Ntoukakis, V.; Jones, J.D.; Shirasu, K.; Menke, F.; Jones, A. Direct regulation of the NADPH oxidase RBOHD by the PRR-associated kinase BIK1 during plant immunity. Mol. Cell 2014, 54, 43-55. [CrossRef] [PubMed]

206. Levine, A.; Tenhaken, R.; Dixon, R.; Lamb, C. $\mathrm{H}_{2} \mathrm{O}_{2}$ from the oxidative burst orchestrates the plant hypersensitive disease resistance response. Cell 1994, 79, 583-593. [CrossRef]

207. Mittler, R.; Herr, E.H.; Orvar, B.L.; Van Camp, W.; Willekens, H.; Inzé, D.; Ellis, B.E. Transgenic tobacco plants with reduced capability to detoxify reactive oxygen intermediates are hyperresponsive to pathogen infection. Proc. Natl. Acad. Sci. USA 1999, 96, 14165-14170. [CrossRef] [PubMed]

208. Lamb, C.; Dixon, R.A. The oxidative burst in plant disease resistance. Ann. Rev. Plant Biol. 1997, 48, $251-275$. [CrossRef] [PubMed]

209. Kärkönen, A.; Kuchitsu, K. Reactive oxygen species in cell wall metabolism and development in plants. Phytochemistry 2015, 112, 22-32. [CrossRef] [PubMed]

210. Cessna, S.G.; Sears, V.E.; Dickman, M.B.; Low, P.S. Oxalic acid, a pathogenicity factor for Sclerotinia sclerotiorum, suppresses the oxidative burst of the host plant. Plant Cell 2000, 12, 2191-2199. [CrossRef] [PubMed]

211. Williams, B.; Kabbage, M.; Kim, H.-J.; Britt, R.; Dickman, M.B. Tipping the balance: Sclerotinia sclerotiorum secreted oxalic acid suppresses host defenses by manipulating the host redox environment. PLoS Pathog. 2011, 7, e1002107. [CrossRef] [PubMed]

212. Lane, B.; Dunwell, J.M.; Ray, J.; Schmitt, M.; Cuming, A. Germin, a protein marker of early plant development, is an oxalate oxidase. J. Biol. Chem. 1993, 268, 12239-12242. [PubMed] 
213. Dumas, B.; Sailland, A.; Cheviet, J.; Freyssinet, G.; Pallett, K. Identification of barley oxalate oxidase as a germin-like protein. C. R. Acad. Sci. Ser. III Sci. 1993, 316, 793-798.

214. Dumas, B.; Freyssinet, G.; Pallett, K.E. Tissue-specific expression of germin-like oxalate oxidase during development and fungal infection of barley seedlings. Plant Physiol. 1995, 107, 1091-1096. [CrossRef] [PubMed]

215. Dong, X.; Ji, R.; Guo, X.; Foster, S.J.; Chen, H.; Dong, C.; Liu, Y.; Hu, Q.; Liu, S. Expressing a gene encoding wheat oxalate oxidase enhances resistance to Sclerotinia sclerotiorum in oilseed rape (Brassica napus). Planta 2008, 228, 331-340. [CrossRef] [PubMed]

216. Donaldson, P.A.; Anderson, T.; Lane, B.G.; Davidson, A.L.; Simmonds, D.H. Soybean plants expressing an active oligomeric oxalate oxidase from the wheat gf-2.8 (germin) gene are resistant to the oxalate-secreting pathogen Sclerotina sclerotiorum. Physiol. Mol. Plant Pathol. 2001, 59, 297-307. [CrossRef]

217. Liu, F.; Wang, M.; Wen, J.; Yi, B.; Shen, J.; Ma, C.; Tu, J.; Fu, T. Overexpression of barley oxalate oxidase gene induces partial leaf resistance to Sclerotinia sclerotiorum in transgenic oilseed rape. Plant Pathol. 2015, 64, 1407-1416. [CrossRef]

218. Liang, H.; Maynard, C.A.; Allen, R.D.; Powell, W.A. Increased Septoria musiva resistance in transgenic hybrid poplar leaves expressing a wheat oxalate oxidase gene. Plant Mol. Biol. 2001, 45, 619-629. [CrossRef] [PubMed]

219. Ramputh, A.; Arnason, J.; Cass, L.; Simmonds, J. Reduced herbivory of the European corn borer (Ostrinia nubilalis) on corn transformed with germin, a wheat oxalate oxidase gene. Plant Sci. 2002, 162, 431-440. [CrossRef]

220. Wei, Y.; Zhang, Z.; Andersen, C.H.; Schmelzer, E.; Gregersen, P.L.; Collinge, D.B.; Smedegaard-Petersen, V.; Thordal-Christensen, H. An epidermis/papilla-specific oxalate oxidase-like protein in the defence response of barley attacked by the powdery mildew fungus. Plant Mol. Biol. 1998, 36, 101-112. [CrossRef] [PubMed]

221. Zimmermann, G.; Bäumlein, H.; Mock, H.-P.; Himmelbach, A.; Schweizer, P. The multigene family encoding germin-like proteins of barley. Regulation and function in basal host resistance. Plant Physiol. 2006, 142, 181-192. [CrossRef] [PubMed]

222. Bradley, D.J.; Kjellbom, P.; Lamb, C.J. Elicitor-and wound-induced oxidative cross-linking of a proline-rich plant cell wall protein: A novel, rapid defense response. Cell 1992, 70, 21-30. [CrossRef]

223. Melotto, M.; Underwood, W.; Koczan, J.; Nomura, K.; He, S.Y. Plant stomata function in innate immunity against bacterial invasion. Cell 2006, 126, 969-980. [CrossRef] [PubMed]

224. Bellincampi, D.; Cervone, F.; Lionetti, V. Plant cell wall dynamics and wall-related susceptibility in plant-pathogen interactions. Front. Plant Sci. 2014, 5, 228. [CrossRef] [PubMed]

225. Kang, Z.; Buchenauer, H. Ultrastructural and cytochemical studies on cellulose, xylan and pectin degradation in wheat spikes infected by Fusarium culmorum. J. Phytopathol. 2000, 148, 263-275. [CrossRef]

226. Wanjiru, W.M.; Zhensheng, K.; Buchenauer, H. Importance of cell wall degrading enzymes produced by Fusarium graminearum during infection of wheat heads. Eur. J. Plant Pathol. 2002, 108, 803-810. [CrossRef]

227. Kong, L.; Anderson, J.M.; Ohm, H.W. Induction of wheat defense and stress-related genes in response to Fusarium graminearum. Genome 2005, 48, 29-40. [CrossRef] [PubMed]

228. Anguelova-Merhar, V.; Westhuizen, A.; Pretorius, Z. $\beta$-1,3-glucanase and chitinase activities and the resistance response of wheat to leaf rust. J. Phytopathol. 2001, 149, 381-384. [CrossRef]

229. Collinge, D.B.; Kragh, K.M.; Mikkelsen, J.D.; Nielsen, K.K.; Rasmussen, U.; Vad, K. Plant chitinases. Plant J. 1993, 3, 31-40. [CrossRef] [PubMed]

230. Broekaert, W.; Van Parijs, J.; Allen, A.; Peumans, W. Comparison of some molecular, enzymatic and antifungal properties of chitinases from thorn-apple, tobacco and wheat. Physiol. Mol. Plant Pathol. 1988, 33, 319-331. [CrossRef]

231. Singh, A.; Kirubakaran, S.I.; Sakthivel, N. Heterologous expression of new antifungal chitinase from wheat. Protein Express. Purif. 2007, 56, 100-109. [CrossRef] [PubMed]

232. van Scheltinga, A.C.T.; Kalk, K.H.; Beintema, J.J.; Dijkstra, B.W. Crystal structures of hevamine, a plant defence protein with chitinase and lysozyme activity, and its complex with an inhibitor. Structure 1994, 2, 1181-1189. [CrossRef]

233. Nagano, N.; Orengo, C.A.; Thornton, J.M. One fold with many functions: The evolutionary relationships between tim barrel families based on their sequences, structures and functions. J. Mol. Biol. 2002, 321, 741-765. [CrossRef] 
234. Leubner-Metzger, G.; Meins, F., Jr. 3 functions and regulation of plant $\beta$-(pr-2). In Pathogenesis-Related Proteins in Plants; CRC Press: Boca Raton, FL, USA, 1999.

235. Doxey, A.C.; Yaish, M.W.; Moffatt, B.A.; Griffith, M.; McConkey, B.J. Functional divergence in the Arabidopsis $\beta-1,3$-glucanase gene family inferred by phylogenetic reconstruction of expression states. Mol. Biol. Evol. 2007, 24, 1045-1055. [CrossRef] [PubMed]

236. Jashni, M.K.; Mehrabi, R.; Collemare, J.; Mesarich, C.H.; De Wit, P.J. The battle in the apoplast: Further insights into the roles of proteases and their inhibitors in plant-pathogen interactions. Front. Plant Sci. 2015, 6, 584. [CrossRef] [PubMed]

237. Thomas, E.L.; van der Hoorn, R.A. Ten prominent host proteases in plant-pathogen interactions. Int. J. Mol. Sci. 2018, 19, 639. [CrossRef] [PubMed]

238. Naumann, T.A.; Wicklow, D.T.; Price, N.P. Identification of a chitinase-modifying protein from Fusarium verticillioides truncation of a host resistance protein by a fungalysin metalloprotease. J. Biol. Chem. 2011, 286, 35358-35366. [CrossRef] [PubMed]

239. Slavokhotova, A.A.; Naumann, T.A.; Price, N.P.; Rogozhin, E.A.; Andreev, Y.A.; Vassilevski, A.A.; Odintsova, T.I. Novel mode of action of plant defense peptides-hevein-like antimicrobial peptides from wheat inhibit fungal metalloproteases. FEBS J. 2014, 281, 4754-4764. [CrossRef] [PubMed]

240. Pekkarinen, A.I.; Longstaff, C.; Jones, B.L. Kinetics of the inhibition of Fusarium serine proteinases by barley (Hordeum vulgare L.) inhibitors. J. Agric. Food Chem. 2007, 55, 2736-2742. [CrossRef] [PubMed]

241. Franco, O.L.; Rigden, D.J.; R Melo, F.; Bloch, C.; Silva, C.P.; Grossi de Sá, M.F. Activity of wheat $\alpha$-amylase inhibitors towards bruchid $\alpha$-amylases and structural explanation of observed specificities. FEBS J. 2000, 267, 2166-2173. [CrossRef]

242. Feng, G.H.; Richardson, M.; Chen, M.S.; Kramer, K.J.; Morgan, T.D.; Reeck, G.R. $\alpha$-amylase inhibitors from wheat: Amino acid sequences and patterns of inhibition of insect and human $\alpha$-amylases. Insect Biochem. Mol. Biol. 1996, 26, 419-426. [CrossRef]

243. Mundy, J.; Svendsen, I.; Hejgaard, J. Barley $\alpha$-amylase/subtilisin inhibitor. I. Isolation and characterization. Carlsberg Res. Commun. 1983, 48, 81-90. [CrossRef]

244. Petrucci, T.; Rab, A.; Tomasi, M.; Silano, V. Further characterization studies of the $\alpha$-amylase protein inhibitor of gel electrophoretic mobility 0.19 from the wheat kernel. Biochim. Biophys. Acta (BBA)-Protein Struct. 1976, 420, 288-297. [CrossRef]

245. Franco, O.L.; Rigden, D.J.; Melo, F.R.; Grossi-de-Sá, M.F. Plant $\alpha$-amylase inhibitors and their interaction with insect $\alpha$-amylases. FEBS J. 2002, 269, 397-412. [CrossRef]

246. Steppuhn, A.; Baldwin, I.T. Resistance management in a native plant: Nicotine prevents herbivores from compensating for plant protease inhibitors. Ecol. Lett. 2007, 10, 499-511. [CrossRef] [PubMed]

247. Shabab, M.; Shindo, T.; Gu, C.; Kaschani, F.; Pansuriya, T.; Chintha, R.; Harzen, A.; Colby, T.; Kamoun, S.; van der Hoorn, R.A. Fungal effector protein AVR2 targets diversifying defense-related CYS proteases of tomato. Plant Cell 2008, 20, 1169-1183. [CrossRef] [PubMed]

248. Rooney, H.C.; van't Klooster, J.W.; van der Hoorn, R.A.; Joosten, M.H.; Jones, J.D.; de Wit, P.J. Cladosporium Avr2 inhibits tomato Rcr3 protease required for Cf-2-dependent disease resistance. Science 2005, 308, 1783-1786. [CrossRef] [PubMed]

249. Song, J.; Win, J.; Tian, M.; Schornack, S.; Kaschani, F.; Ilyas, M.; van der Hoorn, R.A.; Kamoun, S. Apoplastic effectors secreted by two unrelated eukaryotic plant pathogens target the tomato defense protease Rcr3. Proc. Natl. Acad. Sci. USA 2009, 106, 1654-1659. [CrossRef] [PubMed]

250. Lozano-Torres, J.L.; Wilbers, R.H.; Gawronski, P.; Boshoven, J.C.; Finkers-Tomczak, A.; Cordewener, J.H.; America, A.H.; Overmars, H.A.; Van't Klooster, J.W.; Baranowski, L. Dual disease resistance mediated by the immune receptor Cf-2 in tomato requires a common virulence target of a fungus and a nematode. Proc. Natl. Acad. Sci. USA 2012, 109, 10119-10124. [CrossRef] [PubMed]

251. Reisige, K.; Gorzelanny, C.; Daniels, U.; Moerschbacher, B.M. The C28 aldehyde octacosanal is a morphogenetically active component involved in host plant recognition and infection structure differentiation in the wheat stem rust fungus. Physiol. Mol. Plant Pathol. 2006, 68, 33-40. [CrossRef]

252. Tsuba, M.; Katagiri, C.; Takeuchi, Y.; Takada, Y.; Yamaoka, N. Chemical factors of the leaf surface involved in the morphogenesis of Blumeria graminis. Physiol. Mol. Plant Pathol. 2002, 60, 51-57. [CrossRef] 
253. Woloshuk, C.P.; Kolattukudy, P. Mechanism by which contact with plant cuticle triggers cutinase gene expression in the spores of Fusarium solani f. sp. pisi. Proc. Natl. Acad. Sci. USA 1986, 83, 1704-1708. [CrossRef] [PubMed]

254. Oh, I.S.; Park, A.R.; Bae, M.S.; Kwon, S.J.; Kim, Y.S.; Lee, J.E.; Kang, N.Y.; Lee, S.; Cheong, H.; Park, O.K. Secretome analysis reveals an Arabidopsis lipase involved in defense against Alternaria brassicicola. Plant Cell 2005, 17, 2832-2847. [CrossRef] [PubMed]

255. Gottwald, S.; Samans, B.; Lück, S.; Friedt, W. Jasmonate and ethylene dependent defence gene expression and suppression of fungal virulence factors: Two essential mechanisms of Fusarium head blight resistance in wheat? BMC Genom. 2012, 13, 369. [CrossRef] [PubMed]

256. Finkina, E.; Melnikova, D.; Bogdanov, I. Lipid transfer proteins as components of the plant innate immune system: Structure, functions, and applications. Acta Nat. 2016, 8, 47-61.

257. Nimchuk, Z.; Marois, E.; Kjemtrup, S.; Leister, R.T.; Katagiri, F.; Dangl, J.L. Eukaryotic fatty acylation drives plasma membrane targeting and enhances function of several type III effector proteins from Pseudomonas syringae. Cell 2000, 101, 353-363. [CrossRef]

258. Boyes, D.C.; Nam, J.; Dangl, J.L. The Arabidopsis thaliana RPM1 disease resistance gene product is a peripheral plasma membrane protein that is degraded coincident with the hypersensitive response. Proc. Natl. Acad. Sci. USA 1998, 95, 15849-15854. [CrossRef] [PubMed]

259. Leister, R.T.; Ausubel, F.M.; Katagiri, F. Molecular recognition of pathogen attack occurs inside of plant cells in plant disease resistance specified by the Arabidopsis genes RPS2 and RPM1. Proc. Natl. Acad. Sci. USA 1996, 93, 15497-15502. [CrossRef] [PubMed]

260. Abbas, H.K.; Tanaka, T.; Duke, S.O.; Porter, J.K.; Wray, E.M.; Hodges, L.; Sessions, A.E.; Wang, E.; Merrill, A.H., Jr.; Riley, R.T. Fumonisin-and AAL-toxin-induced disruption of sphingolipid metabolism with accumulation of free sphingoid bases. Plant Physiol. 1994, 106, 1085-1093. [CrossRef] [PubMed]

261. Desaki, Y.; Miya, A.; Venkatesh, B.; Tsuyumu, S.; Yamane, H.; Kaku, H.; Minami, E.; Shibuya, N. Bacterial lipopolysaccharides induce defense responses associated with programmed cell death in rice cells. Plant Cell Physiol. 2006, 47, 1530-1540. [CrossRef] [PubMed]

262. Zeidler, D.; Zähringer, U.; Gerber, I.; Dubery, I.; Hartung, T.; Bors, W.; Hutzler, P.; Durner, J. Innate immunity in Arabidopsis thaliana: Lipopolysaccharides activate nitric oxide synthase (NOS) and induce defense genes. Proc. Natl. Acad. Sci. USA 2004, 101, 15811-15816. [CrossRef] [PubMed]

263. Canonne, J.; Froidure-Nicolas, S.; Rivas, S. Phospholipases in action during plant defense signaling. Plant Signal. Behav. 2011, 6, 13-18. [CrossRef] [PubMed]

264. Montillet, J.-L.; Leonhardt, N.; Mondy, S.; Tranchimand, S.; Rumeau, D.; Boudsocq, M.; Garcia, A.V.; Douki, T.; Bigeard, J.; Laurière, C. An abscisic acid-independent oxylipin pathway controls stomatal closure and immune defense in Arabidopsis. PLoS Biol. 2013, 11, e1001513. [CrossRef] [PubMed]

265. Zhao, J. Phospholipase $\mathrm{d}$ and phosphatidic acid in plant defence response: From protein-protein and lipid-protein interactions to hormone signalling. J. Exp. Bot. 2015, 66, 1721-1736. [CrossRef] [PubMed]

266. Rentel, M.C.; Lecourieux, D.; Ouaked, F.; Usher, S.L. Oxi1 kinase is necessary for oxidative burst-mediated signalling in Arabidopsis. Nature 2004, 427, 858-861. [CrossRef] [PubMed]

267. de Zélicourt, A.; Letousey, P.; Thoiron, S.; Campion, C.; Simoneau, P.; Elmorjani, K.; Marion, D.; Simier, P.; Delavault, P. Ha-def1, a sunflower defensin, induces cell death in Orobanche parasitic plants. Planta 2007, 226, 591-600. [CrossRef] [PubMed]

268. Mendez, E.; Moreno, A.; Colilla, F.; Pelaez, F.; Limas, G.G.; Mendez, R.; Soriano, F.; Salinas, M.; Haro, C. Primary structure and inhibition of protein synthesis in eukaryotic cell-free system of a novel thionin, $\gamma$-hordothionin, from barley endosperm. FEBS J. 1990, 194, 533-539. [CrossRef]

269. Colilla, F.J.; Rocher, A.; Mendez, E. Г-purothionins: Amino acid sequence of two polypeptides of a new family of thionins from wheat endosperm. FEBS Lett. 1990, 270, 191-194. [CrossRef]

270. Bruix, M.; Jimenez, M.; Santoro, J.; Gonzalez, C.; Colilla, F.; Mendez, E.; Rico, M. Solution structure of. Gamma. 1-H and gamma. 1-P thionins from barley and wheat endosperm determined by 1H-NMR: A structural motif common to toxic arthropod proteins. Biochemistry 1993, 32, 715-724. [CrossRef] [PubMed]

271. Terras, F.R.G.; Eggermont, K.; Kovaleva, V.; Raikhel, N.V.; Osborn, R.W.; Kester, A.; Rees, S.B.; Torrekens, S.; Van Leuven, F.; Vanderleyden, J. Small cysteine-rich antifungal proteins from radish: Their role in host defense. Plant Cell 1995, 7, 573-588. [CrossRef] [PubMed] 
272. Méndez, E.; Rocher, A.; Calero, M.; Girbés, T.; Citores, L.; Soriano, F. Primary structure of $\omega$-hordothionin, a member of a novel family of thionins from barley endosperm, and its inhibition of protein synthesis in eukaryotic and prokaryotic cell-free systems. FEBS J. 1996, 239, 67-73. [CrossRef]

273. Van Der Weerden, N.L.; Lay, F.T.; Anderson, M.A. The plant defensin, NaD1, enters the cytoplasm of Fusarium oxysporum hyphae. J. Biol. Chem. 2008, 283, 14445-14452. [CrossRef] [PubMed]

274. van der Weerden, N.L.; Hancock, R.E.; Anderson, M.A. Permeabilization of fungal hyphae by the plant defensin NaD1 occurs through a cell wall-dependent process. J. Biol. Chem. 2010, 285, 37513-37520. [CrossRef] [PubMed]

275. Koike, M.; Okamoto, T.; Tsuda, S.; Imai, R. A novel plant defensin-like gene of winter wheat is specifically induced during cold acclimation. Biochem. Biophys. Res. Commun. 2002, 298, 46-53. [CrossRef]

276. Wijaya, R.; Neumann, G.M.; Condron, R.; Hughes, A.B.; Polya, G.M. Defense proteins from seed of Cassia fistula include a lipid transfer protein homologue and a protease inhibitory plant defensin. Plant Sci. 2000, 159, 243-255. [CrossRef]

277. Aerts, A.M.; François, I.E.; Meert, E.M.; Li, Q.-T.; Cammue, B.P.; Thevissen, K. The antifungal activity of RsAFP2, a plant defensin from Raphanus sativus, involves the induction of reactive oxygen species in Candida albicans. J. Mol. Microbiol. Biotechnol. 2007, 13, 243-247. [CrossRef] [PubMed]

278. Spelbrink, R.G.; Dilmac, N.; Allen, A.; Smith, T.J.; Shah, D.M.; Hockerman, G.H. Differential antifungal and calcium channel-blocking activity among structurally related plant defensins. Plant Physiol. 2004, 135, 2055-2067. [CrossRef] [PubMed]

279. Stotz, H.U.; Thomson, J.; Wang, Y. Plant defensins: Defense, development and application. Plant Signal. Behav. 2009, 4, 1010-1012. [CrossRef] [PubMed]

280. García-Olmedo, F.; Molina, A.; Alamillo, J.M.; Rodríguez-Palenzuéla, P. Plant defense peptides. Pept. Sci. 1998, 47, 479-491. [CrossRef]

281. De Paula, V.S.; Razzera, G.; Barreto-Bergter, E.; Almeida, F.C.; Valente, A.P. Portrayal of complex dynamic properties of sugarcane defensin 5 by NMR: Multiple motions associated with membrane interaction. Structure 2011, 19, 26-36. [CrossRef] [PubMed]

282. Lacerda, A.F.; Vasconcelos, É.A.; Pelegrini, P.B.; de Sa, M.F.G. Antifungal defensins and their role in plant defense. Front. Microbiol. 2014, 5, 116. [CrossRef] [PubMed]

283. Vriens, K.; Peigneur, S.; De Coninck, B.; Tytgat, J.; Cammue, B.P.; Thevissen, K. The antifungal plant defensin AtPDF2.3 from Arabidopsis thaliana blocks potassium channels. Sci. Rep. 2016, 6. [CrossRef] [PubMed]

284. Almeida, M.S.; Cabral, K.M.; Kurtenbach, E.; Almeida, F.C.; Valente, A.P. Solution structure of Pisum sativum defensin 1 by high resolution NMR: Plant defensins, identical backbone with different mechanisms of action. J. Mol. Biol. 2002, 315, 749-757. [CrossRef] [PubMed]

285. Brogden, K.A. Antimicrobial peptides: Pore formers or metabolic inhibitors in bacteria? Nat. Rev. Microbiol. 2005, 3, 238-250. [CrossRef] [PubMed]

286. Silverstein, K.A.; Graham, M.A.; Paape, T.D.; VandenBosch, K.A. Genome organization of more than 300 defensin-like genes in arabidopsis. Plant Physiol. 2005, 138, 600-610. [CrossRef] [PubMed]

287. Graham, M.A.; Silverstein, K.A.; Cannon, S.B.; VandenBosch, K.A. Computational identification and characterization of novel genes from legumes. Plant Physiol. 2004, 135, 1179-1197. [CrossRef] [PubMed]

288. Van der Weerden, N.L.; Anderson, M.A. Plant defensins: Common fold, multiple functions. Fungal Biol. Rev. 2013, 26, 121-131. [CrossRef]

289. Wang, S.; Rao, P.; Ye, X. Isolation and biochemical characterization of a novel leguminous defense peptide with antifungal and antiproliferative potency. Appl. Microbiol. Biotechnol. 2009, 82, 79-86. [CrossRef] [PubMed]

290. Ming, D.; Hellekant, G. Brazzein, a new high-potency thermostable sweet protein from Pentadiplandra brazzeana B. FEBS Lett. 1994, 355, 106-108. [CrossRef]

291. Wel, H.; Loeve, K. Isolation and characterization of thaumatin I and II, the sweet-tasting proteins from Thaumatococcus daniellii benth. FEBS J. 1972, 31, 221-225. [CrossRef]

292. Osmond, R.I.; Hrmova, M.; Fontaine, F.; Imberty, A.; Fincher, G.B. Binding interactions between barley thaumatin-like proteins and (1,3)- $\beta$-d-glucans. FEBS J. 2001, 268, 4190-4199. [CrossRef]

293. Bryngelsson, T.; Green, B. Characterization of a pathogenesis-related, thaumatin-like protein isolated from barley challenged with an incompatible race of mildew. Physiol. Mol. Plant Pathol. 1989, 35, 45-52. [CrossRef] 
294. Trümper, C.; Paffenholz, K.; Smit, I.; Kössler, P.; Karlovsky, P.; Braun, H.-P.; Pawelzik, E. Identification of regulated proteins in naked barley grains (Hordeum vulgare nudum) after Fusarium graminearum infection at different grain ripening stages. J. Proteom. 2016, 133, 86-92. [CrossRef] [PubMed]

295. Hejgaard, J.; Jacobsen, S.; Svendsen, I. Two antifungal thaumatin-like proteins from barley grain. FEBS Lett. 1991, 291, 127-131. [CrossRef]

296. Vigers, A.J.; Roberts, W.K.; Selitrennikoff, C.P. A new family of plant antifungal proteins. Mol. Plant Microbe Interact. 1991, 4, 315-323. [CrossRef] [PubMed]

297. Roberts, W.K.; Selitrennikoff, C.P. Zeamatin, an antifungal protein from maize with membrane-permeabilizing activity. Microbiology 1990, 136, 1771-1778. [CrossRef]

298. Abad, L.R.; D’Urzo, M.P.; Liu, D.; Narasimhan, M.L.; Reuveni, M.; Zhu, J.K.; Niu, X.; Singh, N.K.; Hasegawa, P.M.; Bressan, R.A. Antifungal activity of tobacco osmotin has specificity and involves plasma membrane permeabilization. Plant Sci. 1996, 118, 11-23. [CrossRef]

299. Skadsen, R.; Sathish, P.; Kaeppler, H. Expression of thaumatin-like permatin PR-5 genes switches from the ovary wall to the aleurone in developing barley and oat seeds. Plant Sci. 2000, 156, 11-22. [CrossRef]

300. Hahn, M.; Jüngling, S.; Knogge, W. Cultivar-specific elicitation of barley defense reactions by the phytotoxic peptide NIP1 from Rhynchosporium secalis. Mol. Plant Microbe Interact. 1993, 6, 745-754. [CrossRef] [PubMed]

301. Rebmann, G.; Mauch, F.; Dudler, R. Sequence of a wheat cDNA encoding a pathogen-induced thaumatin-like protein. Plant Mol. Biol. 1991, 17, 283-285. [CrossRef] [PubMed]

302. Lin, K.-C.; Bushnell, W.R.; Szabo, L.J.; Smith, A.G. Isolation and expression of a host response gene family encoding thaumatin-like proteins in incompatible oat-stem rust fungus interactions. Mol. Plant Microbe Interact. 1996, 9, 511-522. [CrossRef] [PubMed]

303. Singh, S.; Tripathi, R.K.; Lemaux, P.G.; Buchanan, B.B.; Singh, J. Redox-dependent interaction between thaumatin-like protein and $\beta$-glucan influences malting quality of barley. Proc. Natl. Acad. Sci. USA 2017, 201701824. [CrossRef] [PubMed]

304. Van Loon, L.; Van Strien, E. The families of pathogenesis-related proteins, their activities, and comparative analysis of PR-1 type proteins. Physiol. Mol. Plant Pathol. 1999, 55, 85-97. [CrossRef]

305. Ebrahim, S.; Usha, K.; Singh, B. Pathogenesis related (PR) proteins in plant defense mechanism. Sci. Against Microb Pathog. 2011, 2, 1043-1054.

306. Sinha, M.; Singh, R.P.; Kushwaha, G.S.; Iqbal, N.; Singh, A.; Kaushik, S.; Kaur, P.; Sharma, S.; Singh, T.P. Current overview of allergens of plant pathogenesis related protein families. Sci. World J. 2014, 2014. [CrossRef] [PubMed]

307. Kettles, G.J.; Drurey, C.; Schoonbeek, H.J.; Maule, A.J.; Hogenhout, S.A. Resistance of Arabidopsis thaliana to the green peach aphid, Myzus persicae, involves camalexin and is regulated by microRNAas. New Phytol. 2013, 198, 1178-1190. [CrossRef] [PubMed]

308. Xu, J.; Li, Y.; Wang, Y.; Liu, H.; Lei, L.; Yang, H.; Liu, G.; Ren, D. Activation of MAPK kinase 9 induces ethylene and camalexin biosynthesis and enhances sensitivity to salt stress in Arabidopsis. J. Biol. Chem. 2008, 283, 26996-27006. [CrossRef] [PubMed]

309. Pandey, S.P.; Roccaro, M.; Schön, M.; Logemann, E.; Somssich, I.E. Transcriptional reprogramming regulated by WRKY18 and WRKY40 facilitates powdery mildew infection of Arabidopsis. Plant J. 2010, 64, 912-923. [CrossRef] [PubMed]

310. Ahuja, I.; Kissen, R.; Bones, A.M. Phytoalexins in defense against pathogens. Trends Plant Sci. 2012, 17, 73-90. [CrossRef] [PubMed]

311. Pedras, M.S.C.; Hossain, S.; Snitynsky, R.B. Detoxification of cruciferous phytoalexins in Botrytis cinerea: Spontaneous dimerization of a camalexin metabolite. Phytochemistry 2011, 72, 199-206. [CrossRef] [PubMed]

312. Weibull, J.; Niemeyer, H. Changes in dihydroxymethoxybenzoxazinone glycoside content in wheat plants infected by three plant pathogenic fungi. Physiol. Mol. Plant Pathol. 1995, 47, 201-212. [CrossRef]

313. Wouters, F.C.; Blanchette, B.; Gershenzon, J.; Vassão, D.G. Plant defense and herbivore counter-defense: Benzoxazinoids and insect herbivores. Phytochem. Rev. 2016, 15, 1127-1151. [CrossRef] [PubMed]

314. Givovich, A.; Niemeyer, H. Hydroxamic acids affecting barley yellow dwarf virus transmission by the aphid Rhopalosiphum padi. Entomol. Exp. Appl. 1991, 59, 79-85. [CrossRef]

315. Friebe, A.; Vilich, V.; Hennig, L.; Kluge, M.; Sicker, D. Detoxification of benzoxazolinone allelochemicals from wheat by Gaeumannomyces graminis var. tritici, G. graminis var. graminis, G. graminis var. avenae, and Fusarium culmorum. Appl. Environ. Microbiol. 1998, 64, 2386-2391. [PubMed] 
316. Niemeyer, H.M.; Jerez, J.M. Chromosomal location of genes for hydroxamic acid accumulation in Triticum aestivum L.(wheat) using wheat aneuploids and wheat substitution lines. Heredity 1997, 79. [CrossRef]

317. Osbourn, A.; Clarke, B.; Lunness, P.; Scott, P.; Daniels, M. An oat species lacking avenacin is susceptible to infection by Gaeumannomyces graminis var. tritici. Physiol. Mol. Plant Pathol. 1994, 45, 457-467. [CrossRef]

318. Morrissey, J.P.; Osbourn, A.E. Fungal resistance to plant antibiotics as a mechanism of pathogenesis. Microbiol. Mol. Biol. Rev. 1999, 63, 708-724. [PubMed]

319. González-Lamothe, R.; Mitchell, G.; Gattuso, M.; Diarra, M.S.; Malouin, F.; Bouarab, K. Plant antimicrobial agents and their effects on plant and human pathogens. Int. J. Mol. Sci. 2009, 10, 3400-3419. [CrossRef] [PubMed]

320. Osbourn, A.; Clarke, B.; Dow, J.; Daniels, M. Partial characterization of avenacinase from Gaeumannomyces graminis var. avenae. Physiol. Mol. Plant Pathol. 1991, 38, 301-312. [CrossRef]

321. Wu, H.; Pratley, J.; Lemerle, D.; Haig, T. Allelopathy in wheat (Triticum aestivum). Ann. Appl. Biol. 2001, 139, 1-9. [CrossRef]

322. Adhikari, K.B.; Tanwir, F.; Gregersen, P.L.; Steffensen, S.K.; Jensen, B.M.; Poulsen, L.K.; Nielsen, C.H.; Høyer, S.; Borre, M.; Fomsgaard, I.S. Benzoxazinoids: Cereal phytochemicals with putative therapeutic and health-protecting properties. Mol. Nutr. Food Res. 2015, 59, 1324-1338. [CrossRef] [PubMed]

323. Martinez, D.A.; Loening, U.E.; Graham, M.C. Impacts of glyphosate-based herbicides on disease resistance and health of crops: A review. Environ. Sci. Eur. 2018, 30, 2. [CrossRef] [PubMed]

324. Turlings, T.C.; Tumlinson, J.H.; Lewis, W.J. Exploitation of herbivore-induced plant odors by host-seeking parasitic wasps. Science 1990, 250, 1251. [CrossRef] [PubMed]

325. Turlings, T.C.; Tumlinson, J.H.; Heath, R.R.; Proveaux, A.T.; Doolittle, R.E. Isolation and identification of allelochemicals that attract the larval parasitoid, Cotesia marginiventris (cresson), to the microhabitat of one of its hosts. J. Chem. Ecol. 1991, 17, 2235-2251. [CrossRef] [PubMed]

326. Turlings, T.C.; McCall, P.J.; Alborn, H.T.; Tumlinson, J.H. An elicitor in caterpillar oral secretions that induces corn seedlings to emit chemical signals attractive to parasitic wasps. J. Chem. Ecol. 1993, 19, 411-425. [CrossRef] [PubMed]

327. McKay, S.A.B.; Hunter, W.L.; Godard, K.-A.; Wang, S.X.; Martin, D.M.; Bohlmann, J.; Plant, A.L. Insect attack and wounding induce traumatic resin duct development and gene expression of (-)-pinene synthase in Sitka spruce. Plant Physiol. 2003, 133, 368-378. [CrossRef] [PubMed]

328. Agrawal, A.A.; Konno, K. Latex: A model for understanding mechanisms, ecology, and evolution of plant defense against herbivory. Annu. Rev. Ecol. Evol. Syst. 2009, 40, 311-331. [CrossRef]

329. Becerra, J.X. Squirt-gun defense in bursera and the chrysomelid counterploy. Ecology 1994, 75, $1991-1996$. [CrossRef]

330. Thomson, V.P.; Cunningham, S.A.; Ball, M.C.; Nicotra, A.B. Compensation for herbivory by Cucumis sativus through increased photosynthetic capacity and efficiency. Oecologia 2003, 134, 167-175. [CrossRef] [PubMed]

331. War, A.R.; Paulraj, M.G.; Ahmad, T.; Buhroo, A.A.; Hussain, B.; Ignacimuthu, S.; Sharma, H.C. Mechanisms of plant defense against insect herbivores. Plant Signal. Behav. 2012, 7, 1306-1320. [CrossRef] [PubMed]

332. Cook, R.J.; Thomashow, L.S.; Weller, D.M.; Fujimoto, D.; Mazzola, M.; Bangera, G.; Kim, D.-S. Molecular mechanisms of defense by rhizobacteria against root disease. Proc. Natl. Acad. Sci. USA 1995, 92, 4197-4201. [CrossRef] [PubMed]

333. Campos-Soriano, L.; García-Martínez, J.; Segundo, B.S. The arbuscular mycorrhizal symbiosis promotes the systemic induction of regulatory defence-related genes in rice leaves and confers resistance to pathogen infection. Mol. Plant Pathol. 2012, 13, 579-592. [CrossRef] [PubMed]

334. Song, Y.Y.; Cao, M.; Xie, L.J.; Liang, X.T.; Zeng, R.S.; Su, Y.J.; Huang, J.H.; Wang, R.L.; Luo, S.M. Induction of dimboa accumulation and systemic defense responses as a mechanism of enhanced resistance of mycorrhizal corn (Zea mays L.) to sheath blight. Mycorrhiza 2011, 21, 721-731. [CrossRef] [PubMed]

335. Plett, J.M.; Daguerre, Y.; Wittulsky, S.; Vayssières, A.; Deveau, A.; Melton, S.J.; Kohler, A.; Morrell-Falvey, J.L.; Brun, A.; Veneault-Fourrey, C. Effector MiSSP7 of the mutualistic fungus Laccaria bicolor stabilizes the Populus JAZ6 protein and represses jasmonic acid (JA) responsive genes. Proc. Natl. Acad. Sci. USA 2014, 111, 8299-8304. [CrossRef] [PubMed]

336. Cárdenas, L.; Martínez, A.; Sánchez, F.; Quinto, C. Fast, transient and specific intracellular ROS changes in living root hair cells responding to Nod factors (NFs). Plant J. 2008, 56, 802-813. [CrossRef] [PubMed] 
337. Mitra, R.M.; Long, S.R. Plant and bacterial symbiotic mutants define three transcriptionally distinct stages in the development of the Medicago truncatula/Sinorhizobium meliloti symbiosis. Plant Physiol. 2004, 134, 595-604. [CrossRef] [PubMed]

338. Zhan, J.; Thrall, P.H.; Papaïx, J.; Xie, L.; Burdon, J.J. Playing on a pathogen's weakness: Using evolution to guide sustainable plant disease control strategies. Ann. Rev. Phytopathol. 2015, 53, 19-43. [CrossRef] [PubMed]

339. Shao, F.; Golstein, C.; Ade, J.; Stoutemyer, M.; Dixon, J.E.; Innes, R.W. Cleavage of Arabidopsis PBS1 by a bacterial type III effector. Science 2003, 301, 1230-1233. [CrossRef] [PubMed]

340. Qi, D.; Dubiella, U.; Kim, S.H.; Sloss, D.I.; Dowen, R.H.; Dixon, J.E.; Innes, R.W. Recognition of the protein kinase AVRPPHB SUSCEPTIBLE1 by the disease resistance protein resistance to PSEUDOMONAS SYRINGIAE5 is dependent on S-acylation and an exposed loop in AVRPPHB SUSCEPTIBLE1. Plant Physiol. 2014, 164, 340-351. [CrossRef] [PubMed]

341. Kim, S.H.; Qi, D.; Ashfield, T.; Helm, M.; Innes, R.W. Using decoys to expand the recognition specificity of a plant disease resistance protein. Science 2016, 351, 684-687. [CrossRef] [PubMed]

342. Sarma, B.K.; Singh, H.B.; Fernando, D.; Silva, R.N.; Gupta, V.K. Enhancing plant disease resistance without R genes. Trends Biotechnol. 2016, 34, 523-525. [CrossRef] [PubMed]

343. De Wit, P.J. Host resistance to a fungal tomato pathogen lost by a single base-pair change in an avirulence gene. Nature 1994, 367, 384-386.

344. Zhou, H.; Steffenson, B. Genome-wide association mapping reveals genetic architecture of durable spot blotch resistance in US barley breeding germplasm. Mol. Breed. 2013, 32, 139-154. [CrossRef]

345. Wilcoxson, R.; Rasmusson, D.; Miles, M. Development of barley resistant to spot blotch and genetics of resistance. Plant Dis. 1990, 74, 207-210. [CrossRef]

346. Haas, M.; Menke, J.; Chao, S.; Steffenson, B.J. Mapping quantitative trait loci conferring resistance to a widely virulent isolate of Cochliobolus sativus in wild barley accession PI 466423. Theor. Appl. Genet. 2016, 129, 1831-1842. [CrossRef]

347. Valjavec-Gratian, M.; Steffenson, B. Pathotypes of Cochliobolus sativus on barley in North Dakota. Plant Dis. 1997, 81, 1275-1278. [CrossRef] 